\title{
Permo-Carboniferous conglomerates in the Trinity Peninsula Group at View Point, Antarctic Peninsula: sedimentology, geochronology and isotope evidence for provenance and tectonic setting in Gondwana
}

\author{
JOHN D. BRADSHAW* ${ }^{*}$, ALAN P. M. VAUGHAN \\ FLOWERDEW $\ddagger$ RUDOLPH A. J. TROUW \\ WHITEHOUSE\# \\ *Department of Geological Sciences, University of Canterbury, P.B. 4800, Christchurch 8140, New Zealand \\ $\ddagger$ British Antarctic Survey, High Cross, Madingley Road, Cambridge CB3 0ET, UK \\ §NIGL, British Geological Survey, Kingsley Dunham Centre, Keyworth, Nottingham NG12 5GG, UK \\ TUniversidade Federal de Rio de Janeiro, Depto. de Geologia, Av. Athos da Silveira Ramos 274, 21.946-916 Rio de \\ Janeiro, Brazil \\ ||PRISE, Research School of Earth Sciences, The Australian National University, Mills Road, Canberra ACT 0201, \\ Australia \\ \#Swedish Museum of Natural History, Box 50007, S-104 05 Stockholm, Sweden
}

(Received 25 October 2010; accepted 1 July 2011; first published online 24 October 2011)

\begin{abstract}
Field observations from the Trinity Peninsula Group at View Point on the Antarctic Peninsula indicate that thick, southward-younging and overturned clastic sedimentary rocks, comprising unusually coarse conglomeratic lenses within a succession of fine-grained sandstonemudstone couplets, are the deposits of debris and turbidity flows on or at the foot of a submarine slope. Three detrital zircons from the sandstone-mudstone couplets date deposition at $302 \pm 3 \mathrm{Ma}$, at or shortly after the Carboniferous-Permian boundary. Conglomerates predominantly consist of quartzite and granite and contain boulders exceeding $500 \mathrm{~mm}$ in diameter. Zircons from granitoid clasts and a silicic volcanic clast yield $\mathrm{U}-\mathrm{Pb}$ ages of $466 \pm 3 \mathrm{Ma}, 373 \pm 5 \mathrm{Ma}$ and $487 \pm 4 \mathrm{Ma}$, respectively and have corresponding average $\varepsilon \mathrm{Hf}_{\mathrm{t}}$ values between +0.3 and +7.6. A quartzite clast, conglomerate matrix and sandstone interbedded with the conglomerate units have broadly similar detrital zircon age distributions and Hf isotope compositions. The clast and detrital zircon ages match well with sources within Patagonia; however, the age of one granite clast and the $\varepsilon \mathrm{Hf}$ characteristics of some detrital zircons point to a lesser South Africa or Ellsworth Mountain-like contribution, and the quartzite and granite-dominated composition of the conglomerates is similar to upper Palaeozoic diamictites in the Ellsworth Mountains. Unlike detrital zircons, large conglomerate clasts limit possible transport distance, and suggest sedimentation took place on or near the edge of continental crust. Comparison with other upper Palaeozoic to Mesozoic sediments in the Antarctic Peninsula and Patagonia, including detrital zircon composition and the style of deformation, suggests deposition of the Trinity Peninsula Group in an upper plate basin on an active margin, rather than a subduction-related accretionary setting, with slow extension and rifting punctuated by short periods of compression.
\end{abstract}

Keywords: geochronology, Pacific margin, sedimentation, glaciation, zircon, Hf.

\section{Introduction}

Rocks of the Trinity Peninsula Group occur widely in the northern Antarctic Peninsula, and the South Shetland and South Orkney islands. They are the substrate for the Mesozoic-Cenozoic-age arcs of the Antarctic Peninsula (Smellie, 1991; Willan, 2003) and form the Trinity Peninsula Group Province of Vaughan \& Storey (2000). Metamorphic rocks occurring as xenoliths in granite are thought to represent rocks that underlie the group and show links to Patagonia (Hervé et al. 1996). The group is considered to include the Miers Bluff Formation of the South Shetland Islands (Hervé et al. 2006) and the Greywacke-Shale

†Author for correspondence: john.bradshaw@canterbury.ac.nz
Formation of the South Orkney Islands (Trouw et al. 1997). All these units have a similar association of facies and similar provenance (Andreis, Ribeiro \& Trouw, 1997) but better dating of sedimentation and deformation events suggests that they be better regarded as two or more tectonosedimentary tracts. The rocks typically comprise successions that have been regarded as turbidites from middle and lower submarine fan settings and have been variously interpreted as a fore-arc basin (Dalziel, 1984; Storey \& Garrett, 1985) or a slope basin in the upper part of an accretionary complex (Smellie, Roberts \& Hirons, 1996). Despite these differences, there appears to be a consensus that the rocks evolved on the Pacific margin of the Gondwana continent in a subduction-driven setting (e.g. Willan, 2003), though not necessarily in their 


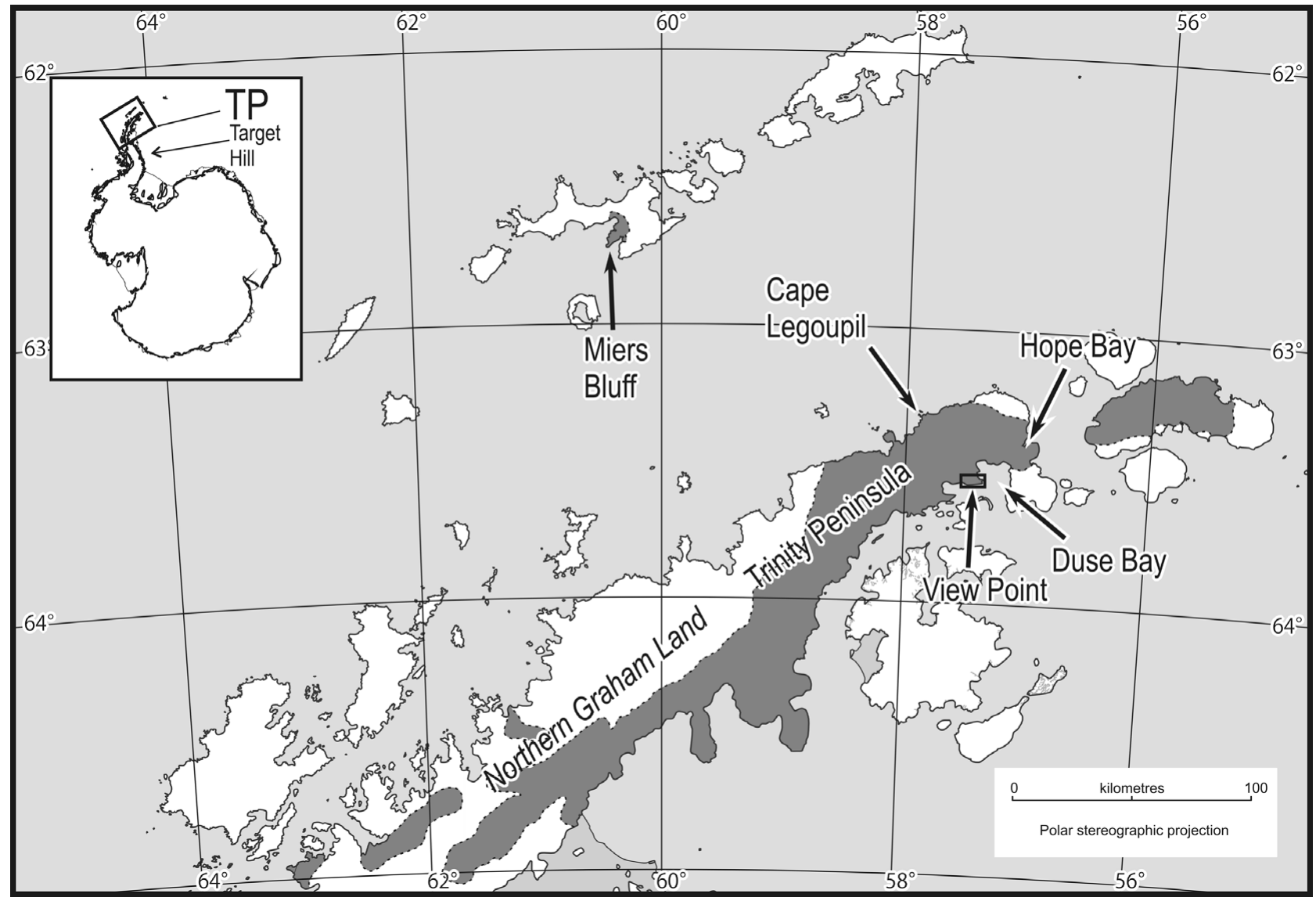

Figure 1. Map of localities mentioned in the text and outcrop distribution of the Trinity Peninsula Group (dark grey) in the northern Antarctic Peninsula (after Paciullo et al. 2002).

current location (Vaughan \& Livermore, 2005). Age control for the Trinity Peninsula Group is not strong. The only palaeontological age constraint comes from the South Orkney Islands where Triassic microfossils are reported (Dalziel et al. 1981) and where the upper age limit is constrained by subduction-related deformation and metamorphism of Early Jurassic age (Flowerdew, Daly \& Riley, 2007). Similarly, Lower Jurassic alluvial fan deposits of the Botany Bay Group (Hunter et al. 2005) rest unconformably on the turbidites at Hope Bay, and Triassic fossils occur within an allochthonous sedimentary olistolith at Cape Legoupil (Thompson, 1975) (Fig. 1). On the other hand, ${ }^{40} \mathrm{~K}-{ }^{39} \mathrm{Ar}$ geochronology suggested some parts of the group could be of Early Permian or Carboniferous age (Smellie \& Millar, 1995). Detrital zircon geochronology results from the northern Antarctic Peninsula (Millar et al. 2003) and more detailed data in Barbeau et al. (2010), show strong Permian peaks and suggest Permian or Triassic depositional ages at the oldest. From the South Shetland Islands, Hervé et al. (1996) reported Middle Jurassic zircons from the Miers Bluff Formation, a unit that is considered part of the Trinity Peninsula Group.

In texture and composition, the Trinity Peninsula Group (Doktor, Swierczewsku \& Tokarski, 1994; Smellie, 1991) resembles contemporaneous subduction-driven regional assemblages such as the Torlesse rocks of New Zealand (Mackinnon, 1983;
Wandres et al. 2004). Proximity to an active volcanic arc is not supported by the petrology of the majority of the group (Willan, 2003) in which quartz and feldspar are sub-equal, and approximately one third of the feldspar is potassic and includes microcline and perthitic grains. Biotite is also common. Lithic fragments constitute only a small percentage of the rock and are mainly of acid and intermediate composition (Doktor, Swierczewsku \& Tokarski, 1994). Derivation from a contemporaneous or older continental margin arc with widespread plutonic rocks is indicated (Smellie, 1991; also compare Wandres et al. 2004). An exception is the Hope Bay succession that is richer in volcanic detritus possibly derived from the Early Permian arc of the North Patagonia Massif (Willan, 2003). The structure of the rocks at Hope Bay also differs and the relationship to the remainder of the group is uncertain.

\section{The View Point assemblage}

View Point $\left(63^{\circ} 33^{\prime} \mathrm{S}, 057^{\circ} 23^{\prime} \mathrm{W}\right)$ is a small headland that sits at the western side of the entrance to Duse Bay in the hook of Trinity Peninsula on the eastern coast of Graham Land (Fig. 1). It forms a peninsula that strikes ENE-WSW and ranges in altitude from sea level at its eastern end to $350 \mathrm{~m}$ in the west. The peninsula is about $6 \mathrm{~km}$ long and $2.5 \mathrm{~km}$ wide. 


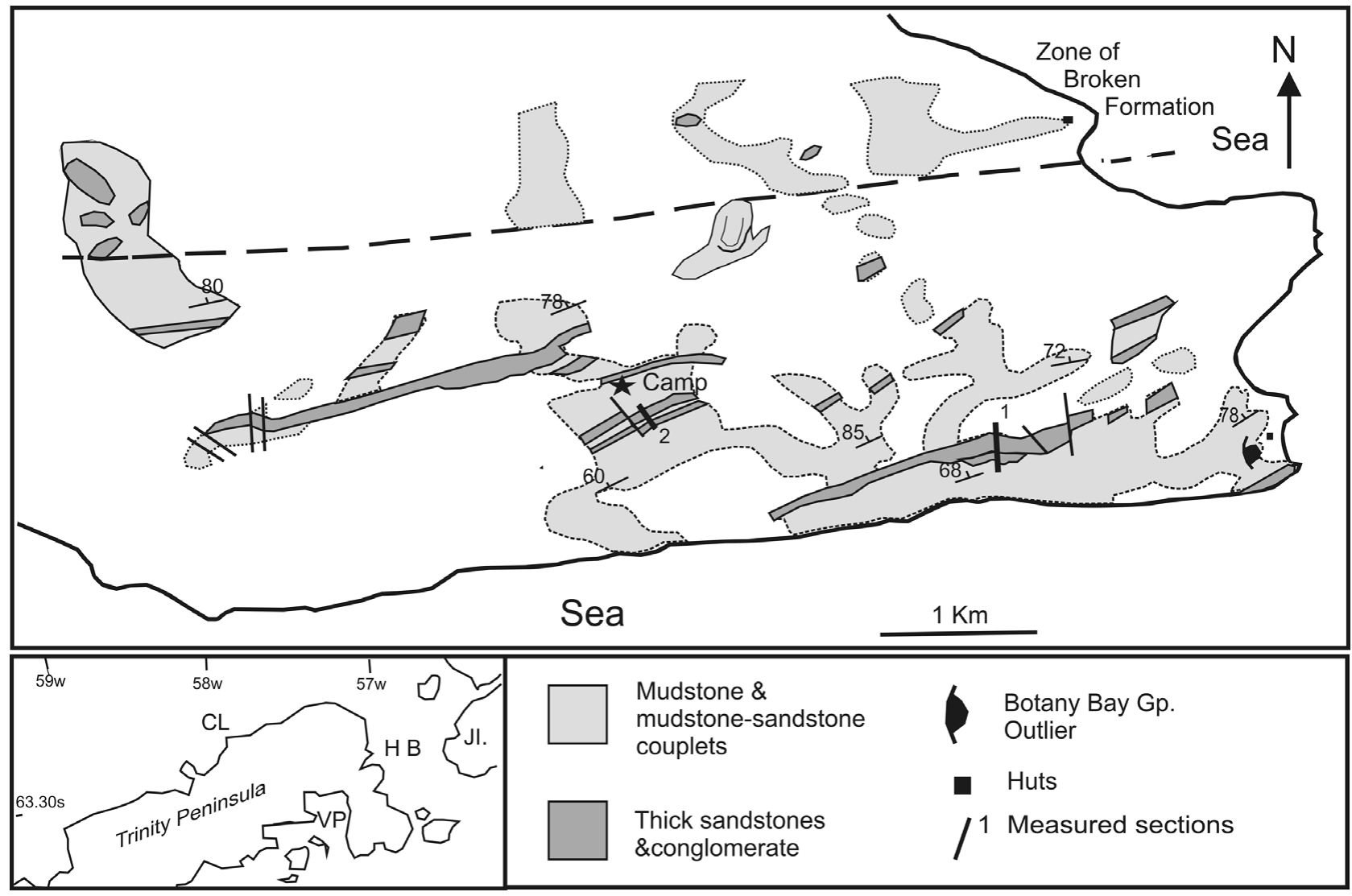

Figure 2. Map of the bed-rock geology in the View Point area. Inset map, location of View Point. VP - View Point; HB - Hope Bay; CL - Cape Legoupil; JI - Joinville Island.

The assemblage described from within the peninsula differs from others Trinity Peninsula Group sequences so far described in having horizons of thick sandstone (Fig. 2) containing coarse to very coarse conglomerate that provides further insights into provenance and depositional setting. The View Point area was described by Aitkenhead (1965) who recorded the presence of conglomerate at two isolated localities; however, a substantial decrease in the snow and ice cover in the area in recent years has allowed mapping as part of this study to reveal that the conglomerates form at least ten separate units, individually up to $15 \mathrm{~m}$ thick with clasts up to $1.3 \mathrm{~m}$ in diameter, and to be much more abundant than previously documented. On the peninsula, the rocks are strongly deformed and generally overturned, dipping steeply to the north and younging to the south. The inverted rocks are truncated by an unconformity at the base of a very small, partly fault-bounded outlier of sedimentary breccia close to the tip of View Point (Fig. 2). These rocks closely resemble the Middle Jurassic Botany Bay Group at Hope Bay, $24 \mathrm{~km}$ to the northeast (Fig. 1). This correlation supports a Jurassic or older age for the deposits and deformation.

\section{Sedimentary facies}

There are two dominant sedimentary facies. The most voluminous comprises thinly bedded to laminated siltstone to very fine sandstone with variable thicknesses of mudstone interbeds. Less in volume but better exposed are bands of pale weathering sandstone and conglomerate. Two bands are continuous across more than half the area and a minimum of six bands can be mapped for some distance along strike. Mapping of the thinner bands is complicated by the presence of small folds and small faults with apparent dextral and sinistral components and by extensive blockfields. Thickness measurements on the larger sandstone bands and the distribution of conglomerate within them suggest that the coarse bands are lenticular (Fig. 2).

\section{3.a. Thinly bedded lithologies}

In fresh outcrop these lithologies appear very dark grey or black and might be mistaken for massive mudstone, but partial weathering reveals, in abundant fine detail, thin beds of silt and very fine sandstone. There are wide variations in the sandstone to mudstone ratio and individual sandy layers range from 1 to $50 \mathrm{~mm}$ in thickness (Fig. 3). Thicker beds in the $20-50 \mathrm{~mm}$ range may have well-developed ripple-scale crosslaminations and at the top show an upward gradation into mudstone. Sandstones of this type sometimes show sole structures of either eroded or collapsed bedding parallel burrows or, more rarely, small scale flutes. Load structures and flames are also developed. The thicker units can be described as $\mathrm{T}_{\mathrm{bcd}}$ and $\mathrm{T}_{\mathrm{cd}}$ 

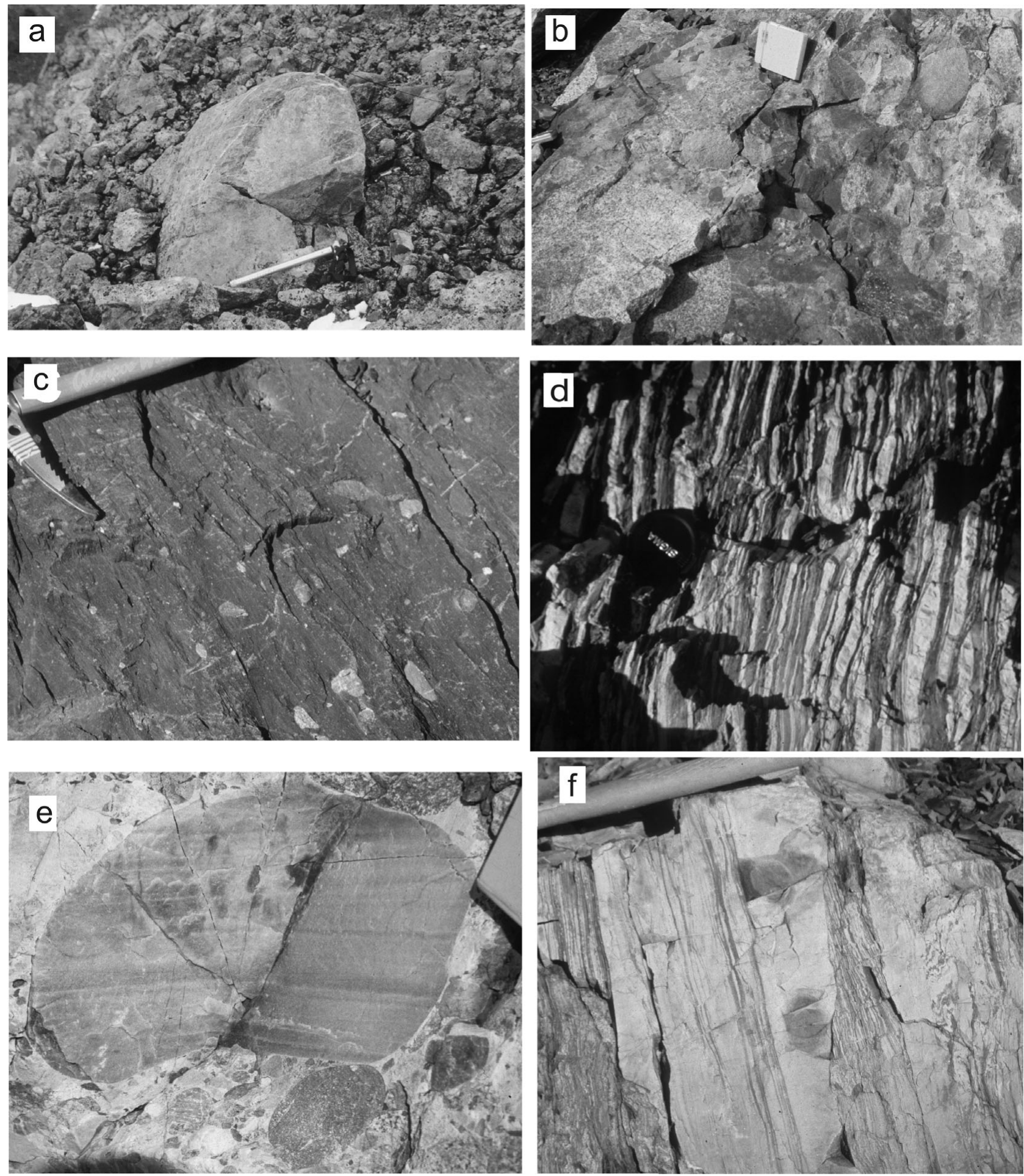

Figure 3. Selected outcrop photographs of the Trinity Peninsula Group near View Point. (a) Large (approximately $1.3 \mathrm{~m}$ ) boulder in conglomerate bed (ice axe is $750 \mathrm{~mm}$ long). (b) Typical clast-supported conglomerate (notebook is 170 by $105 \mathrm{~mm}$ ). (c) Pebbly mudstone. (d) Typical sandstone-mudstone couplets. (e) Large $(430 \mathrm{~mm}$ ) rounded boulder of bedded quartzite. (f) Thicker sandstones $(100-150 \mathrm{~mm})$ within sandstone-mudstone couplets. Note erosive base of sandstone. Rocks young to left (south).

turbidites (Walker, 1992) and the thinner laminae could also be the deposits of low energy turbid flows or bottom currents. Bottom energy appears to have been extremely low but true pelagic claystone appears to be absent.
Rare but widespread beds of pebbly mudstone and muddy fine sandstone occur. The pebbles are rounded and include quartzite and granitoid granules to cobbles. Pebbly mudstone also occurs within the 'broken formation' belt and the original conglomerate 
locality of Aitkenhead (1965) appears to have been one of these occurrences.

\section{3.b. Thickly bedded lithologies}

These lithologies comprise sandstone and conglomerate beds with minor mudstone interbeds developed in bodies from $10 \mathrm{~m}$ to more than $100 \mathrm{~m}$ in thickness (Figs 2 to 5). The sandstone is usually medium to fine grained, in some cases with a few millimetres of coarse sand at the base and a weakly developed gradation through fine sandstone into siltstone in the top 10-20 mm. Many of the thicker sandstone beds have layers of quartz granules and/or mudstone clasts that suggest levels of amalgamation between successive sedimentation events. In section 1 (Fig. 4) amalgamated units reach $20 \mathrm{~m}$ in thickness and are separated by thin layers typical of the thin-bedded association. Mudstone 'rip-up clasts' up to $500 \mathrm{~mm}$ in length occur in a few sandstone beds, particularly near their bases. The bases of some sandstone beds are clearly erosive and truncate thinly bedded rocks at surfaces with a relief of up to $400 \mathrm{~mm}$. This erosion probably accounts for at least some of the mudstone clasts.

Granule to boulder conglomerate may occur at any level within the sandstone units in layers up to $4 \mathrm{~m}$ thick. Despite their thickness, the development of conglomerate beds is highly variable along strike within the sandstone units and conglomerate rapidly grades laterally into sandstone. Conglomerate types range from unstratified poorly sorted pebble to cobble conglomerate (Fig. 3) with dispersed larger boulders (350$1300 \mathrm{~mm}$ ), through well-organized clast-supported pebble to cobble conglomerate with sandstone to granule matrix, to beds of sandstone with $10-20 \%$ granules and rare small pebbles. Most conglomerates were ungraded but grading was seen near the base or near the top in some instances. Reverse grading was evident in a number of beds (Figs $4 \& 5$ ). Cross-bedding was not present in either sandstone or conglomerate and imbrication was not observed.

The clasts in the conglomerates are moderately to very well rounded. Clast counts were made at three localities. A one-metre square was used and compositions noted at $100 \mathrm{~mm}$ grid intersections. Areas of very coarse conglomerate were avoided because a few very large clasts would unbalance the numbers. All three sites produced very similar results and simple average values are reported here. The largest and most abundant clasts are quartzite (50\%) and granitoids (25\%), and these were also the most common type of very large boulder. The remaining $25 \%$ were mainly other sandstones, some feldspathic $(12 \%)$, acid and intermediate volcanic rocks $(10 \%)$, and mafic volcanic rocks ( $3 \%$ ), accompanied by rare small-pebble conglomerate, and very rare fossiliferous sandstone and limestone with indeterminate shelly fossils of probable Palaeozoic age (M. Williams pers. comm. 2006). No metamorphic rocks were seen. Some very large quartzite boulders were elongate parallel to their own internal bedding (Fig. 3) and some large granitoids were sub-quadrate, possibly reflecting the original joint pattern and spacing in the source granitoid.

\section{Depositional setting}

Sedimentological research on the Trinity Peninsula Group during the last two decades has consistently identified turbidite sedimentation in a submarine fan setting (e.g. Andreis, Ribeiro \& Trouw, 1997; Paciullo et al. 2002; Ribeiro et al. 2002) and favoured development in a mid-fan lobe environment. Facies models for submarine fan sedimentation have been proposed by Pickering et al. (1986) and Walker (1992). These authors recognize seven major facies associations (A to G) and at least four of these can be recognized in the View Point succession. They are (A) gravels, muddy gravels, gravely muds and pebbly sands, (B) sands, (C) sand-mud couplets and sandy muds, and (D) silty muds and silt-mud couplets. This classification has been applied to the measured section (Fig. 4). These lithologies are also present in the sections described in the papers cited above, but the View Point succession differs from the others in the common presence of coarse conglomerate.

Volumetrically, the View Point succession is dominated by very thinly bedded fine-grained rocks that on slightly weathered surfaces show 'Bouma' interval patterns $T_{\text {bcd }}$ or $T_{\text {cd. }}$. They can be equated with facies $\mathrm{C}$ and D of Pickering et al. (1986), and are probably the deposits of low energy turbidity flows or other deep-water currents. They reflect prevalent conditions of sedimentation at View Point. The gravely deposits (facies A) are the most varied part of the succession and can be accommodated in the same facies classification framework and is indicated on Figure 4. Closely related to the conglomerates in the field are sandstones with less than $5 \%$ pebbles, typically thick/medium-bedded disorganized sands, sometimes clearly in amalgamated groups (Fig. 4) corresponding to facies B1 of Pickering et al. (1986).

Pickering et al. (1986) suggested that their facies $\mathrm{A}$ and $\mathrm{B}$ deposits are mainly turbidites and to a lesser extent debris flows. On the other hand, Shanmugam (2006) has argued that much sandy bathyal sedimentation is the result of debris flows and that the turbidite model has been too freely applied to deep-water sandy deposits. The View Point deposits with their abundance of boulders in excess of $300 \mathrm{~mm}$ show features characteristic of the deposits of debris flows and a lack the features of turbidites. These facies A rocks are probably debrites. They are closely associated with and pass laterally into thick facies B type sandstones (Figs $4 \& 5$ ) and therefore it is likely that many of these enclosing sandstones were deposited in the same debris flow process.

Other parts of the Trinity Peninsula Group (see next Section) have been interpreted as turbidites from supra-fan lobes in a middle fan setting. At View 


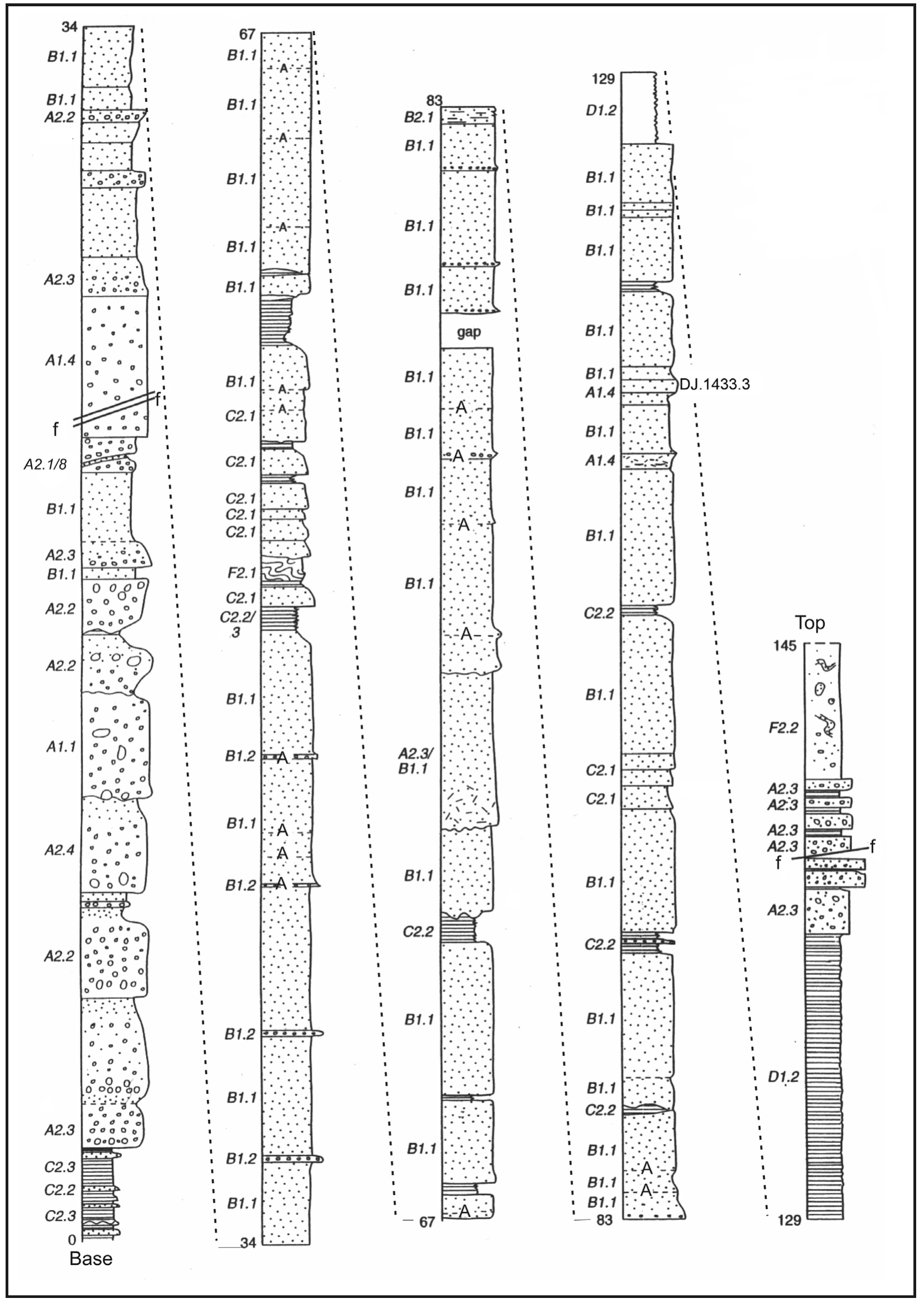

Figure 4. Details of longest measured section (number 1 on Fig. 2), with class descriptors of Pickering et al. (1986). 'A' in columns indicates amalgamation surfaces; $\mathrm{f}-$ fault. The stratigraphic base is in the sharp ridge at $063.5538^{\circ} \mathrm{S} 057.4017^{\circ} \mathrm{W}$. The section is drawn conventionally but the base is at the top of the hill in a section that is inverted and continues down the south face. 


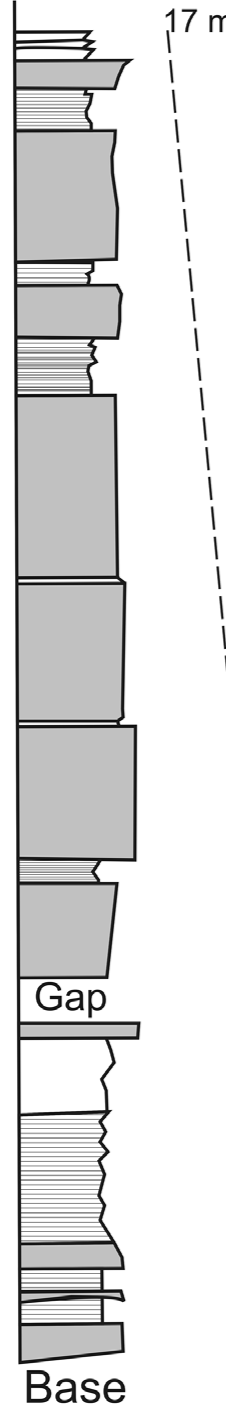

mi

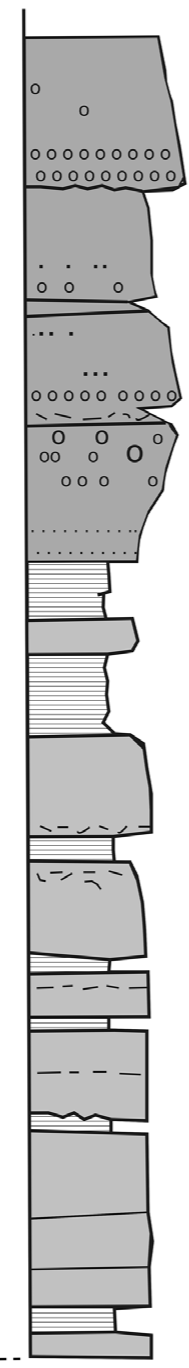

Sandstone \& conglomerate

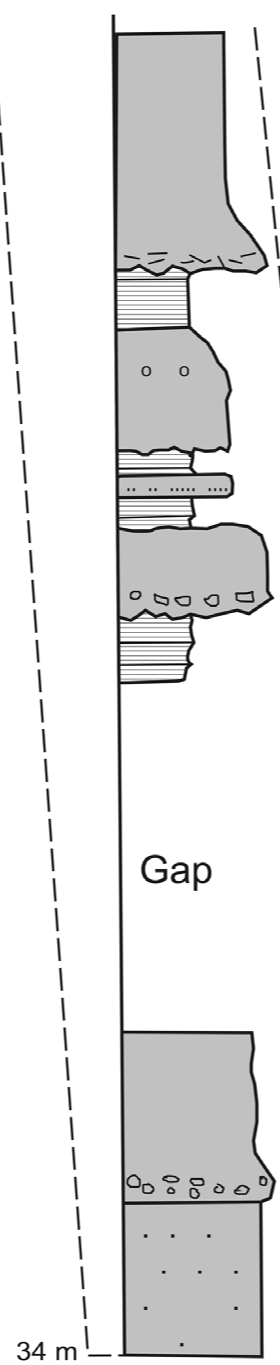

Sandstone-mudstone couplets

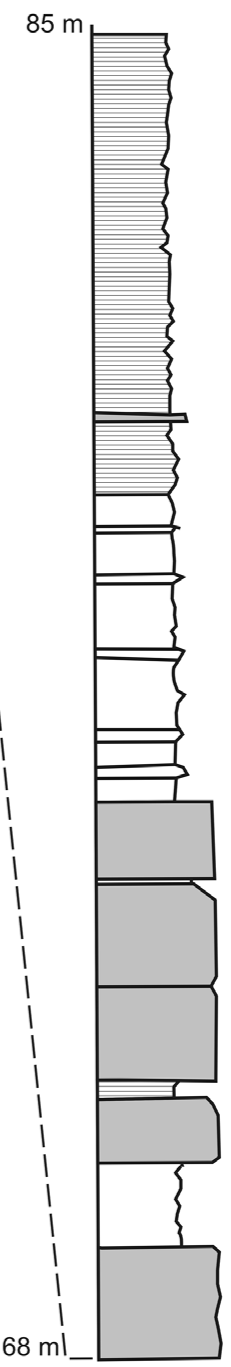

Massive mudstone + siltstone bands

Figure 5. Simplified section (number 2 on Fig. 2) to the south of the camp at $063.5546^{\circ} \mathrm{S} 057.4516^{\circ} \mathrm{W}$. The stratigraphic base is at this location and the section is inverted and youngs to the south on a gentle slope.

Point there appears to be a sharp contrast between the distal character of the fine-grained sediments and very proximal character of the conglomerates. This could be interpreted as an upper fan or canyon mouth assemblage, or alternatively deposits at the base of a submarine slope or shelf edge with periodic sedimentgravity flows.

\section{Comparisons with other sections}

Paciullo et al. (2002) reported in detail the succession at Hope Bay. There are two main sandstone-rich bodies, which occur above and below the thin central fine-grained member. Their columns (Paciullo et al. 2002, figs 4 \& 5) show $500 \mathrm{~m}$ of section, over half measured in detail. Most of the thickness is made up of massive sandstone classified as Bouma $T_{a}$ or poorly developed $\mathrm{T}_{\mathrm{ab}}$ or $\mathrm{T}_{\mathrm{ac}}$. In addition there are laminated sandstones composed of Bouma $T_{b}$ intervals, and alternating sandstone-mudstone packages in which Bouma patterns $\mathrm{T}_{\mathrm{ae}}, \mathrm{T}_{\mathrm{ab}}, \mathrm{T}_{\mathrm{abd}}$ or $\mathrm{T}_{\mathrm{bde}}$ can be recognized.

Another interesting Trinity Peninsula Group assemblage occurs to the west of Hope Bay near Cape Legoupil (Fig. 1) and has been described by Ribeiro et al. (2002). They presented seven representative stratigraphic columns, each showing about $25 \mathrm{~m}$ of section. Sediments in their columns, (A-C of fig. 3) are sandstone dominated and the interpretation is similar to that reported from Hope Bay. Columns D and E are mudstone dominated with thin sandstones, only 
one of which is shown to be graded, and column $F$ includes a thick debris flow deposit. The relative proportions of the various types of sediment are not reported, but their map of Largo Island shows that sandstone is dominant through a succession of about $500 \mathrm{~m}$. The area is unusual in the presence on Gandara Island of a very large olistolith of fossiliferous shallow marine sediment at least $50 \mathrm{~m}$ thick and at least $500 \mathrm{~m}$ wide as judged from the reported occurrence on the adjacent Kopaitic Island. The succession is sandstone dominated, with cross-bedding, ripple marks and thin lenses of conglomerate. Originally considered to be of Cretaceous age, the brachiopod and gastropod fossils were subsequently shown to be of Triassic age (Thompson, 1975). Ribeiro et al. (2002) considered the host succession to be made up of turbidites deposited in a mid-fan setting and the olistolith to have been derived from a submarine canyon wall or submarine slope. It is difficult to envisage, however, that an extensive but thin slab (aspect ratio 10:1) could be detached from a submarine canyon wall and transported to a mid-fan position. As with View Point, a base of slope setting remains a viable alternative and suggests that a range of sedimentary environments are represented in the Trinity Peninsula Group.

\section{Composition and provenance}

Petrological studies of the Trinity Peninsula Group (Doktor, Swierczewsku \& Tokarski, 1994; Smellie, 1991; Willan, 2003) show that the group is characterized mainly by quartzo-feldspathic sandstones with a variable and commonly small proportion of lithic clasts. This is consistent with the data from the View Point conglomerates, where the high proportion of quartzite and granitoid clasts also suggests provenance from a sedimentary terrane with granitic intrusions. The sparse occurrence of volcanic clasts in the conglomerates is also consistent with sandstone composition in the more felsic Petrofacies II of Smellie (1991; see also Willan, 2003). Willan's (2003) data indicate that View Point and Hope Bay are distinctly different in QFL composition, being more quartzose and more felsic, respectively, than the average. In Chile, composition of sandstones in both the accretionary Duque de York Complex and in the Eastern Andes Metamorphic Complex (east of the Cretaceous batholith) are also quartzo-feldspathic (Faundez, Herve \& Lacassie, 2002) and overlap with Trinity Peninsula Group sandstones and resemble most closely Petrofacies I of Smellie (1991).

The conglomerate clasts at View Point are important because they provide large specimens of the rocks in their source area and constrain transport distances in fluvial and marine environments, in contrast to detrital zircons that may be far travelled. The large clasts are dominated by quartzite and granitoid boulders. The proportions and compositions of larger clast types strongly resemble the tillites and marine glacial sediments of the upper Palaeozoic Whiteout
Conglomerate of the Ellsworth Mountains (Matsch \& Okangas, 1992). The Ellsworth Mountains rocks differ in being mainly diamictites with abundant finegrained matrix. They also include higher percentages of shale and limestone clasts (some with archaeocyathid fossils) than are seen at View Point. It is clear, however, that despite considerable variation through the $1000 \mathrm{~m}$ thickness of the Whiteout Conglomerate, quartzite and granite boulders are always the most abundant and that quartzite always exceeds granite (Matsch \& Okangas, 1992, table 1). This compositional pattern is not seen in the Dwyka tillites of southern Africa, where igneous rocks, usually granite, are the dominant component and are accompanied by schist, carbonate rocks (including rare archaeocyathid limestone) and banded iron formation (Visser, Hall \& Loock, 1986). The Fitzroy Tillite in the Falkland Islands (West Falkland) includes common quartzite and a wide range of other lithologies (Aldiss \& Edwards, 1999; Stone \& Thomson, 2005) including archaeocyathid limestone blocks (Stone \& Thomson, 2005). Archaeocyatha are known from the Cambrian of the Transantarctic Mountains and South Australia and point to a significant Antarctic contribution to these tillites. The dominant quartzite plus granite composition at View Point and the Ellsworth Mountains is distinctive and suggests either a common source or possibly secondary source for the View Point conglomerates in Carboniferous-Permian glacial diamictites or related outwash conglomerates of similar composition. The Ellsworth Mountains are probably a relatively small portion of a larger icecovered tectonic block that originated in the AntarcticSouth Africa portion of Gondwana. More specific interpretation is hindered by the allochthonous position of the Ellsworth Mountains and other crustal blocks of West Antarctica (Chernicoff \& Zappettini, 2003; Curtis, 2001; König \& Jokat, 2006).

While not identical, there are important similarities between the View Point assemblage and the PliocenePleistocene mega-channel deposits of the tectonically active Alaskan margin (Eyles \& Lagoe, 1998). Here thinly bedded turbidites are cut by broad channels that include conglomerates and massive sandstones. They differ from the View Point rocks in the common presence of dropstones and the clearly defined channel geometry. The absence of dropstones may indicate that the View Point rocks were either deposited beyond the range of floating ice or at a time of waning glaciation when montane glaciers or ice caps no longer reached the coast. The lack of recognizable channels may simply reflect the smaller area, discontinuous exposure and structural inversion. The View Point thick sandstones and conglomerate beds, with their distinctive grain size and detrital zircon population (see Section 7) probably represent the reworking of conglomerates of Carboniferous or earliest Permian age, probably glacial deposits derived from continental rocks of Gondwana. The matrix of the conglomerate was derived from the same source and does not include the abundant middle Permian zircons typical of Trinity Peninsula 
Table 1. Summary of $\mathrm{U}-\mathrm{Pb}$ zircon geochronology from View Point

\begin{tabular}{lllllll}
\hline Sample & Stratigraphical unit & \multicolumn{1}{c}{ Lithology } & Latitude & Longitude & Event & Age $(\mathrm{Ma})^{1}$ \\
\hline DJ.1405.2 & sandstone & sandstone & $063.5554^{\circ} \mathrm{S}$ & $057.4265^{\circ} \mathrm{W}$ provenance & $300,500,560,620,1110,2700$ \\
DJ.1433.3 & sandstone & sandstone & $063.5538^{\circ} \mathrm{S}$ & $057.4107^{\circ} \mathrm{W}$ & provenance & $495,550,620,1010,2780$ \\
DJ.1336.9 & conglomerate & white granite clast & $063.5512^{\circ} \mathrm{S}$ & $057.4622^{\circ} \mathrm{W}$ & plutonism & $373 \pm 5$ \\
DJ.1336.3 & conglomerate & granite gneiss clast & $063.5512^{\circ} \mathrm{S}$ & $057.4622^{\circ} \mathrm{W}$ & plutonism & $467 \pm 3$ \\
R.752.2 & conglomerate & granite clast & $063.55^{\circ} \mathrm{S}$ & $057.35^{\circ} \mathrm{W}$ & plutonism & $463 \pm 5^{*}$ \\
DJ.1412.4 & conglomerate & volcanic clast & $063.5533^{\circ} \mathrm{S}$ & $057.4099^{\circ} \mathrm{W}$ & volcanism & $487 \pm 4$ \\
DJ.1412.2 & conglomerate & quartzite clast & $063.5533^{\circ} \mathrm{S}$ & $057.4099^{\circ} \mathrm{W}$ & provenance & $500,560,1110,2720$ \\
R.752.4 & conglomerate & granite clast & $063.55^{\circ} \mathrm{S}$ & $057.35^{\circ} \mathrm{W}$ & plutonism & $3161 \pm 13^{*}$
\end{tabular}

1. asterisk indicates data from Millar, Pankhurst \& Fanning (2002). All other data are from this study.

Group rocks of probable Triassic age. The revised interpretation is consistent with derivation from an uplifted continental margin with felsic plutonic rocks as suggested by Smellie (1991). The immediate source of the conglomeratic units was probably Carboniferous glacial or glacial outwash units exposed on the shelf edge or locally uplifted parts of the continental margin.

Although a glacial origin for the boulders cannot be proven, the alternatives require specific circumstances. Large boulders $(>500 \mathrm{~mm})$ usually occur within mountain valleys and do not escape much beyond the range-front by fluvial transport. Most large boulders are deposited in alluvial fans close to the mountains and only if these intersect the coast do boulders in any quantity reach the sea where they form coast parallel bars or fan deltas. Only where submarine canyon heads reach close to the coastline can cobble- or boulderrich materials reach deep water. Another alternative is submarine rock avalanches or fault scarp collapse. Both these explanations require high relief and/or active tectonics close to the site of the basin. The rounding of most boulders in the conglomerates is not consistent with this explanation. These alternative explanations require a tectonically active area of continental crust relatively close to the site of deposition.

\section{Detrital zircon geochronology and Hf isotope geochemistry}

In this paper we present $\mathrm{U}-\mathrm{Pb}$ geochronology and $\mathrm{Lu}-\mathrm{Hf}$ isotope geochemistry of zircons separated from six conglomerate clasts and two sandstones collected from the View Point assemblage of the Trinity Peninsula Group. Results are summarized in Table 1 and $\mathrm{U}-\mathrm{Pb}$ data are given in Table $\mathrm{S} 1$ and $\mathrm{Lu}-\mathrm{Hf}$ data in Table S2 in online Appendix 2 at http://journals.cambridge.org/geo, which also contains a more detailed description of the analysed samples.

$\mathrm{U}-\mathrm{Pb}$ zircon SIMS geochronology was completed at the Australian National University, Canberra and at the Swedish Museum of Natural History, Stockholm and the analytical procedures are outlined by Williams (1998) and Whitehouse, Kamber \& Moorbath (1999), respectively. Following geochronology, hafnium isotope compositions of the zircons were measured by laser ablation ICP-MS at the NERC isotope Geosciences Laboratory, Keyworth, Nottingham, UK following the method of Flowerdew et al. (2006). Further analytical details are given in online Appendix 1 at http://www.journals.cambridge.org/geo. In the following text and diagrams 2 sigma uncertainties are given for all ages and $\varepsilon \mathrm{Hf}$ values, unless otherwise indicated.

\section{7.a. Igneous clasts}

Most of the zircons separated from granite gneiss clast (DJ.1336.3) are bright and prismatic with aspect ratios of 2:1 and exhibit classic growth zoning under cathode luminescence (CL), a feature normally attributed to magmatic growth (Fig. 6; Corfu et al. 2003). Fourteen of 15 analyses from such grains yield a concordia age of $466 \pm 3 \mathrm{Ma}$ that dates crystallization of the granite protolith. A few less well faceted and rounded grains are markedly different under CL with complex and non-luminescent patterns, and these grains yield older ages. In view of the lack of zoned magmatic overgrowth, the older grains are interpreted to have been inherited during emplacement of the granite, perhaps from a sedimentary host. The Ordovician magmatic zircons yield $\varepsilon \mathrm{Hf}$ values ranging between -6.5 and +5.2 with a weighted average of $0.3 \pm 2.1$, a value that corresponds to a depleted mantle model age of $1073 \mathrm{Ma}$ (Table S2 in online Appendix 2 at http://www.journals.cambridge.org/geo).

The white granite clast (DJ.1336.9) yielded stubby, well-faceted, CL-bright prismatic zircons with growth zoning, yielding a concordia age of $373 \pm 5 \mathrm{Ma}$ (Fig. 6) that dates crystallization of the granite protolith. Like the granite gneiss clast (above), rare grains with more rounded morphologies and different $\mathrm{CL}$ characters yield older ages and are similarly interpreted as inherited during emplacement. The magmatic zircons with $\varepsilon H f$ values between +3.9 and +14.2 yield a weighted average of $+7.6 \pm 3.5$, a value corresponding to a depleted mantle model age of $699 \mathrm{Ma}$.

Zircons from volcanic clast (DJ.1412.4) are euhedral, well-faceted grains with aspect ratios of 2:1 that display growth zoning under CL. Although the analyses spread slightly along concordia (Fig. 6) the weighted mean of the ${ }^{206} \mathrm{~Pb}-{ }^{238} \mathrm{U}$ ages for all 18 analyses yields an age of $487 \pm 4 \mathrm{Ma}$, which is considered to date eruption of the volcanic protolith. Zircons yield $\varepsilon \mathrm{Hf}$ values between -1.0 and +7.9 and yield a weighted 

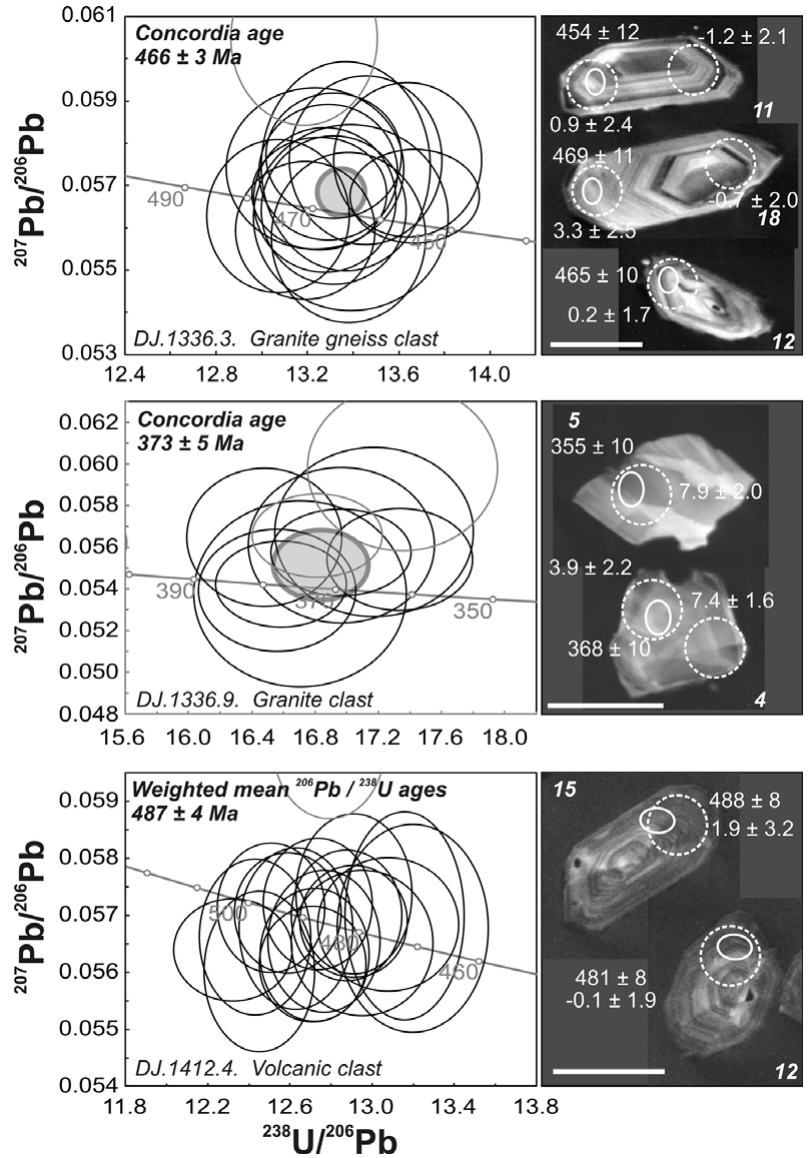

Figure 6. Concordia diagrams for igneous cobbles from the View Point conglomerate. Panels to the right show representative $\mathrm{CL}$ images of zircons and the location of analysis spots after zircon geochronology (solid) and Hf isotope geochemistry (dashed). Scale bar with the zircon images is $100 \mu \mathrm{m}$.

average of $+2.2 \pm 2.6$, a value corresponding to a depleted mantle model age of $783 \mathrm{Ma}$.

We also present $\varepsilon H f$ geochemical data for zircons from granite clasts with ages of $464 \pm 5 \mathrm{Ma}$ and $3161 \pm 13 \mathrm{Ma}$ (Table S2 in online Appendix 2 at http://journals.cambridge.org/geo), originally dated by Millar et al. (2002).

\section{7.b. Sedimentary rocks}

The quartzite clast (DJ.1412.2), conglomerate matrix (DJ.1433.3) and the background sandstone-mudstone facies to the conglomerate/sandstone units (DJ.1405.2) have remarkably similar detrital zircon age distributions (Fig. 7). Concordia diagrams and CL images of detrital grains are presented in Figure 8. In all cases the most abundant populations are at $495-500 \mathrm{Ma}$, $620 \mathrm{Ma}, 1020-1110 \mathrm{Ma}$ and 2700-2780 Ma. Relative probability plots constructed with or without discordant data are very similar. Only the sandstone-mudstone couplet (DJ.1405.2) from the voluminous thinly bedded facies demonstrates that the succession is significantly younger than the Late Devonian granite clast. The sample yielded three concordant grains with a weighted mean age of $302 \pm 3$ Ma indicating that the View Point

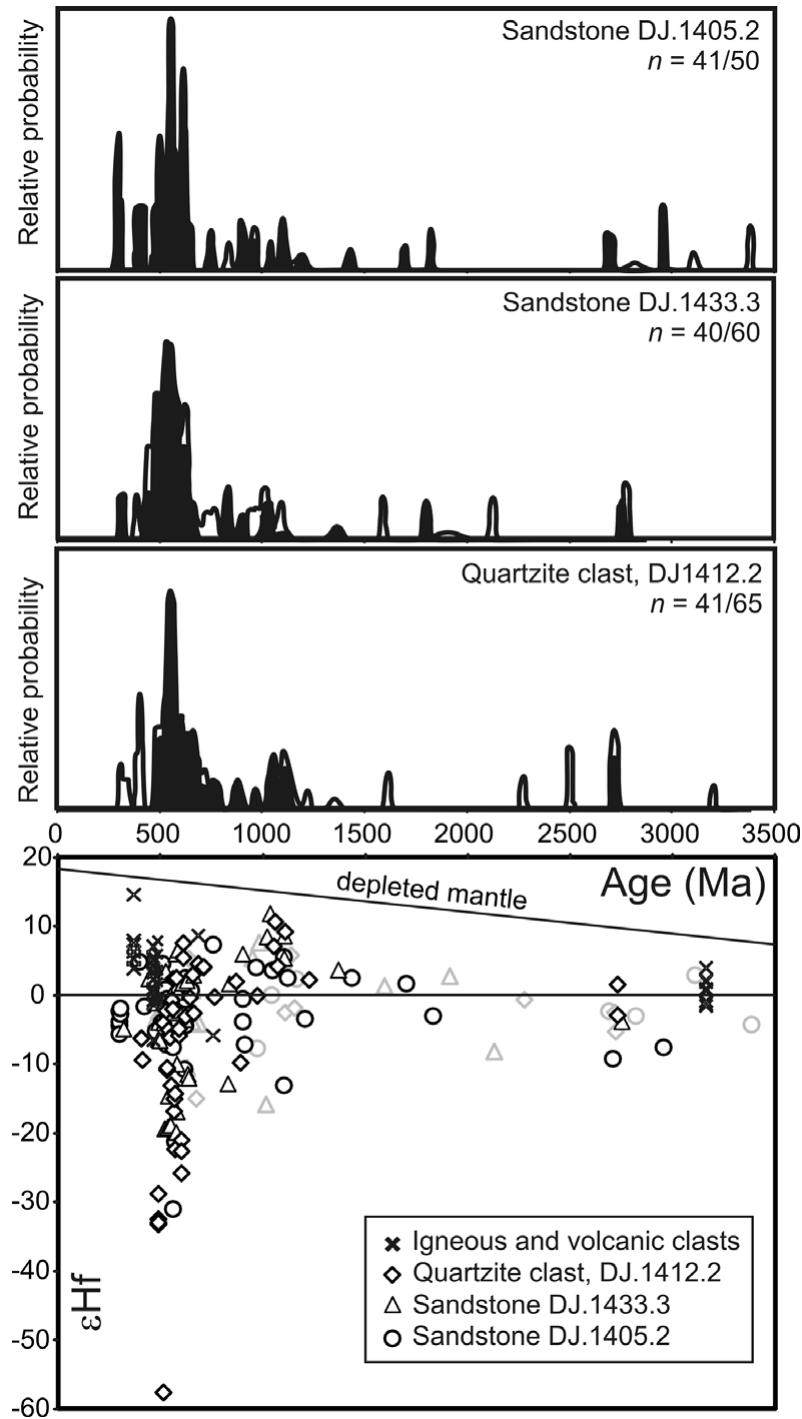

Figure 7. Top panels show cumulative frequency distribution plots for the three (meta)sandstone clasts. Filled distributions represent concordant data only and the number of concordant out of the total analysed is given to the right of each panel with the sample number. The black line represents the cumulative frequency distribution when all data, concordant (within $2 \sigma$ uncertainty) and discordant, are included in the plot construction. Bottom panel shows the $\varepsilon$ Hf versus age distribution for the samples together with those from the igneous clasts. Grey markers indicate $\mathrm{Hf}$ analyses performed on zircon whose $\mathrm{U}-\mathrm{Pb}$ age is discordant.

succession was deposited at or after the CarboniferousPermian boundary that is placed by Ogg, Ogg \& Gradstein (2008) at 299.0 Ma.

The $\varepsilon$ Hf values for the detrital zircons are also similar for each sample (Fig. 7). The majority of the dominant $\sim 500-620$ Ma grains in each sample yielded $\varepsilon \mathrm{Hf}$ values between approximately -8 and +2 , corresponding to depleted mantle model ages of between $1500 \mathrm{Ma}$ and $1000 \mathrm{Ma}$. Each sample contained a significant proportion of zircons in this age range with much more negative $\varepsilon \mathrm{Hf}$ values, with groupings at approximately $-15,-22$ and -30 , corresponding to depleted mantle model ages of 

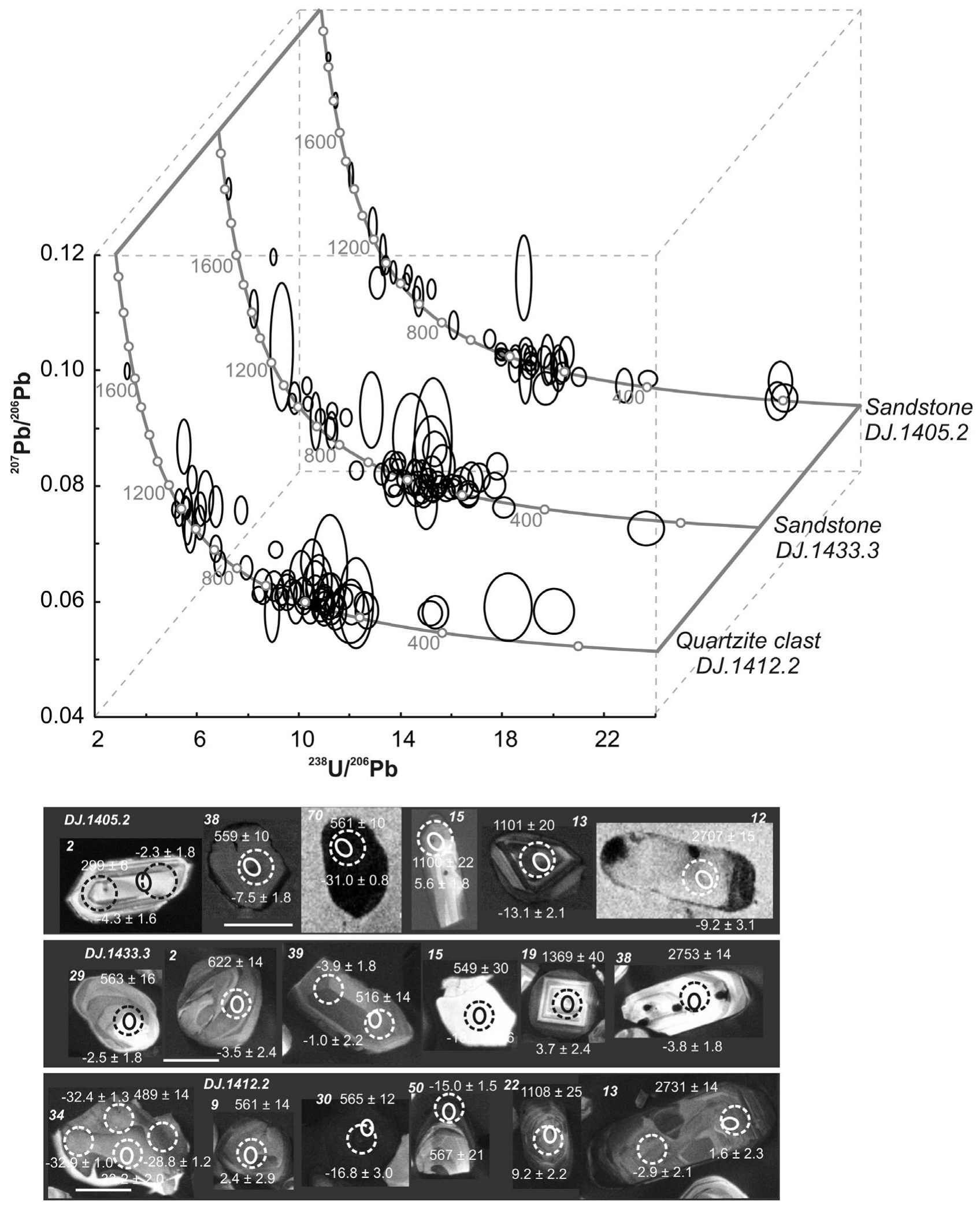

Figure 8. Concordia diagram for (meta)sedimentary cobbles from the View Point conglomerate and sandstone beds. Panel below shows representative CL images for each sample with the location of spots from zircon geochronology (solid) and Hf isotope geochemistry (dashed). Scale bar is $100 \mu \mathrm{m}$.

$\sim 1740,1980$ and 2300 Ma. Quartzite clast DJ.1412.2 has one $\sim 513 \mathrm{Ma}$ grain with an $\varepsilon \mathrm{Hf}$ value of -58 , which results in a $\sim 3290$ Ma depleted mantle model age. The other significant detrital zircon age populations that are shared by each sample also share similar $\varepsilon H f$ compositions. The majority of the 1000 $1100 \mathrm{Ma}$ grains have positive $\varepsilon \mathrm{Hf}$ values ranging between +2 and +12 , corresponding to depleted mantle model ages between $\sim 1550 \mathrm{Ma}$ and $1100 \mathrm{Ma}$. The $\sim 2700-2780$ Ma populations have negative $\varepsilon \mathrm{Hf}$ 
values of $\sim-3$ and a depleted mantle model age of $\sim$ $3210 \mathrm{Ma}$. The young $\sim 300$ Ma grains, which are only present in sandstone sample DJ.1405.2, have $\varepsilon H f$ values of approximately -3.5 with a corresponding depleted mantle model age of $\sim 1070 \mathrm{Ma}$.

\section{Interpretation of the geochronology and Hf isotope geochemistry}

The granite and granite gneiss cobbles are of Middle Ordovician age and the third granite is of Late Devonian age. Granites of very similar ages ( $474 \pm 6$ Ma to 476 $\pm 6 \mathrm{Ma})$ are reported from the Sierra Grande area of the North Patagonia Massif (Pankhurst et al. 2006) and similar but less well constrained ages from granite in the Deseado Massif of southern Patagonia (Pankhurst et al. 2003). Granitoids within this range are also reported from the Famatinian arc in the Sierras Pampeanas further to the north (Chernicoff et al. 2010; Dahlquist et al. 2008). The volcanic clast is early Ordovician in age and silicic volcanic rocks of similar age (477 $\pm 4 \mathrm{Ma}$ ) also occur in the Famatinian arc (Dahlquist et al. 2008). Granite cobbles with zircons in a similar range of ages (between 460 and $490 \mathrm{Ma}$ ) also occur in the basal Permian La Golondrina Formation of the Deseado Massif(Pankhurst et al.2003), but the absence of Permian detrital zircons in the matrix at View Point suggests that it is older than the La Golondrina Formation, although the clasts may be derived from a similar source. The Devonian granite clast is, within error, the same age as a granite $(371 \pm 4 \mathrm{Ma})$ from the southwestern part of the North Patagonia Massif (Pankhurst et al. 2006). The Archaean granite has an age $(3161 \pm 13 \mathrm{Ma})$ and $\mathrm{Hf}$ isotope composition that matches closely with the Kaapvaal Craton of South Africa (Zeh, Gerdes \& Barton, 2009).

Alternative sources for the Ordovician granites are not compelling. They lie outside the range of crystallization ages for the Cambrian-earliest Ordovician granites of the Ross-Delamerian orogen of the Transantarctic Mountains and southern Australia (Foden et al. 2006). Similarly, they do not correspond to the Cambrian ages recently determined from the Tierra del Fuego basement (Hervé et al. 2010) or to Late Precambrian-Cambrian granites in southern Africa (Scheepers \& Armstrong, 2002). The granites are older than ages reported from orthogneiss in southern Graham Land and western Palmer Land (Harrison \& Piercy, 1991; Millar, Pankhurst \& Fanning, 2002; Milne \& Millar, 1991).

Alternatives sources for the Devonian granites are difficult to find despite the common occurrence of Devonian zircon in sediments. Hervé, Fanning \& Pankhurst (2003) suggested that granites of this age may be more abundant than present exposures suggest or lie outside South America. A possible hypothesis is that the Lachlan Orogen of Australia-northern Victoria Land and western Marie Byrd Land (Bradshaw, 2007) extends into eastern Marie Byrd Land with a similar range of granite ages to those seen in SE Australia (Birch, 2003) and Tasmania (Black et al. 2005).

Detrital zircons from a quartzite clast are dominated by a complex grouping between 500 and $700 \mathrm{Ma}$ accompanied by significant grouping around $1000 \mathrm{Ma}$ (across the Neoproterozoic-Mesoproterozoic boundary) and a scattering of Palaeoproterozoic and Archaean ages. This suggests an early Palaeozoic age for quartzite sedimentation. The pattern is one commonly seen along the Gondwana margin, particularly in the SW Pacific region (Ireland et al. 1998), extending into the Ellsworth-Whitmore Mountains (Flowerdew et al. 2007) and also represented in pre-Carboniferous rocks of Patagonia (Pankhurst et al. 2003, 2006). Drilling has also revealed Cambrian granodioritic gneiss in the basement of Tierra del Fuego (Hervé et al. 2010; Pankhurst et al. 2003; Söllner, Millar \& Herve, 2000). These occurrences support an extension of the Pampean Orogen into eastern Patagonia including the southern Deseado terrane, a region regarded as an allochthonous crustal block by Pankhurst et al. (2006) that had amalgamated (or reunited) with northern Patagonia by the Permian period. Hervé et al. (2010) reported evidence of a high-grade metamorphic event of Permian age in Tierra del Fuego.

Detrital zircons from the sandstone matrix from the View Point conglomerate show a similar pattern with most ages between 490 and $650 \mathrm{Ma}$ and a scattering of older ages. A Ross-Delamerian contribution (490$650 \mathrm{Ma}$ ) is typical of Gondwana margin Palaeozoic rocks. Rather surprisingly, detrital zircons of an age corresponding to that of the granite clasts have not been found. A few grains give younger apparent ages, including a single grain that gives concordant ages at $320 \pm 5 \mathrm{Ma}$. This is thought to be a true age and indicates a source in Late Carboniferous igneous rocks and is, within error, similar to ages $(321 \pm$ $2 \mathrm{Ma}, 318 \pm 2 \mathrm{Ma}$ and $323 \pm 3 \mathrm{Ma}$ ) reported from northern Patagonia by Pankhurst et al. (2006). It is, however, also close to the ages of granites at Target Hill (Millar, Pankhurst \& Fanning, 2002), about $350 \mathrm{~km}$ SSW of View Point. These few grains are the only representatives of post-Cambrian populations that are well represented in other South American basins (Augustsson et al. 2006; Bahlburg et al. 2009). This raises some doubts about the provenance of the matrix sediment and a need to consider possible alternative sources. Sediments and metasediments in Dronning Maud Land, the Ellsworth-Whitmore Mountains and the southern Antarctic Peninsula have 500-650 Ma and 1000-1200 Ma aged populations and $\varepsilon \mathrm{Hf}$ consistent with origin from 1000-1500 Ma crust (Flowerdew, Millar \& Vaughan, 2006; Flowerdew et al. 2007; Veevers \& Saeed, 2007). Rocks of similar age and Hf composition are exposed in the Shackleton Range (Will et al. 2009, 2010) and at Haag Nunataks (Flowerdew et al. 2007). More important perhaps, are the $\sim 550 \mathrm{Ma}$ grains that have extreme negative $\varepsilon \mathrm{Hf}$ values and form a 'keel' on Figure 9. Grains of this age and Hf signature are apparently rare from South America 


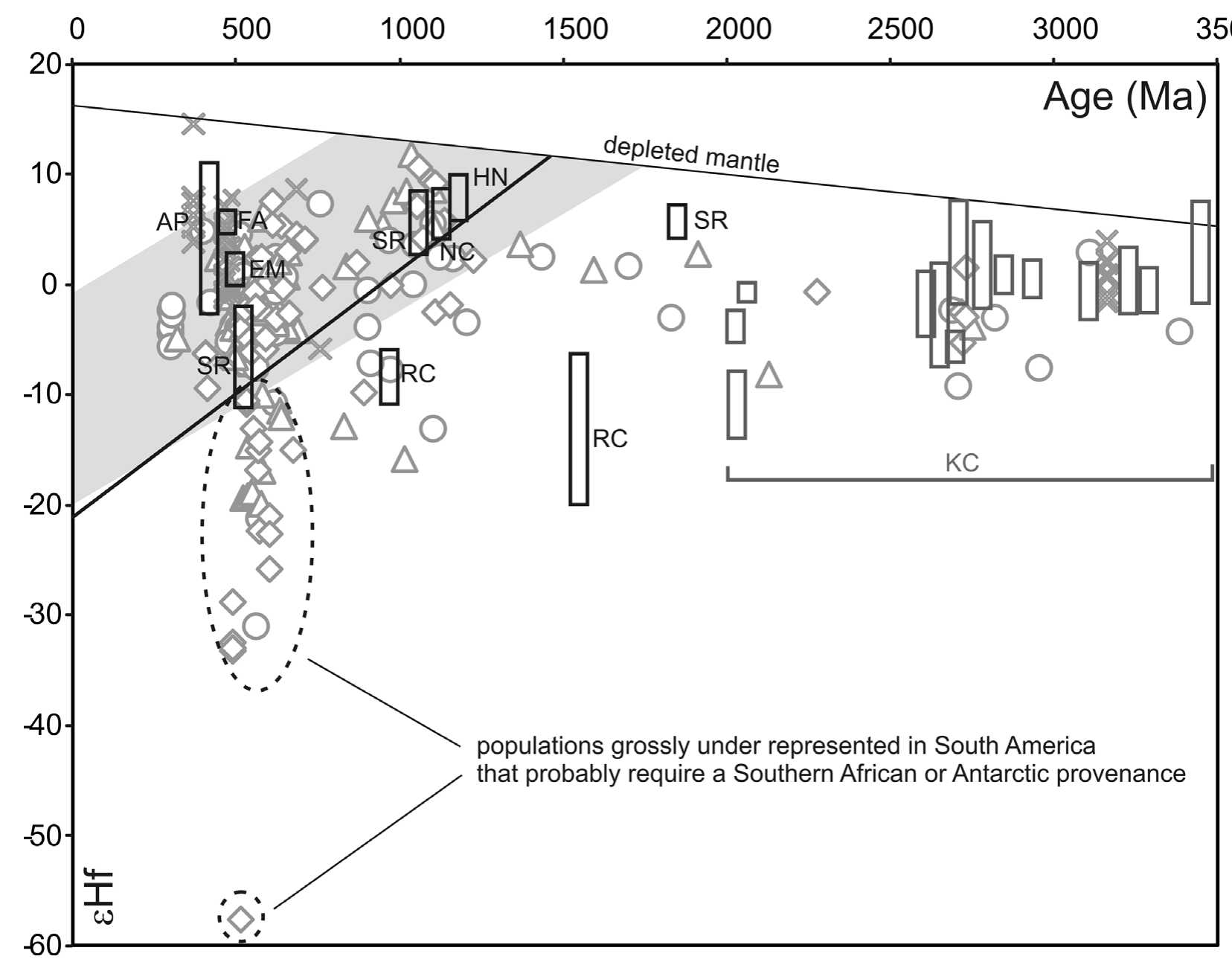

Figure 9. Grey markers show age against $\varepsilon H f$ from this study (diamonds - quartzite clast DJ1412.2; triangles - sandstone DJ.1433.3; circles - DJ.1405.2; crosses - igneous cobbles, undifferentiated) and are overlain with bars representing the range of potential igneous and volcanic source rocks, identified by the adjacent abbreviation, from South America, Antarctica and South Africa: AP - Antarctic Peninsula, EM - Ellsworth Mountains, Antarctica; FA - Famatinian arc, South America; HN - Haag Nunataks, Antarctica; KC Kaapvaal craton, southern Africa; NC - Nampula Complex, southern Africa; RC - Rayner Complex, Antarctica; SR - Shackleton Range, Antarctica. (Data from Chernicoff et al. 2010; Flowerdew, Millar \& Vaughan, 2006; Halpin et al. 2005; Thomas et al. 2010; Will et al. 2010; Zeh, Gerdes \& Barton, 2009.)

(Bahlburg et al. 2009) but are relatively abundant in the upper parts of the Ellsworth Mountains succession (Flowerdew et al. 2007) and also from sediments and cobbles in Mesozoic sedimentary rocks from the southern Antarctic Peninsula (Flowerdew, Millar \& Vaughan, 2006). Flowerdew et al. (2007) proposed these grains must have originated from southern Africa, but with respect to the View Point succession, it is entirely possible that detritus was first deposited in the Ellsworth-Whitmore Mountains block or a geologically similar crustal fragment and then recycled into the View Point basin in Late Carboniferous times. These considerations resonate with the quartzitegranite-dominated character of the large clasts in both the diamictites of the Ellsworth Mountains and the View Point conglomerates discussed above and points, at least in part, to a common provenance. It is also consistent with a southern Target Hill area source for the Late Carboniferous zircons.

In contrast, detrital zircon spectra from the group in other parts of the Trinity Peninsula show distinctly different ages. Five recently published detrital zircon age spectra from the Trinity Peninsula Group (Barbeau et al. 2010) show a predominance of Permian zircons in all samples with major peaks in the range 270-280 Ma. One sample, from the most southerly location at Lahille Island, Leroux Bay showed a significantly younger peak at $260 \mathrm{Ma}$. A sixth sample from the Botany Bay Group (Jurassic age) shared the 280 Ma peak, although these rocks rest unconformably on folded and metamorphosed Trinity Peninsula Group rocks. These ages are consistent with our previously unpublished detrital zircon data from Gaston Islands and Hope Bay that show strong populations with essentially the same 'middle Permian' age (around $275 \pm 5 \mathrm{Ma}$ ) forming $30 \%$ and $60 \%$ of analysed grains, respectively. These rocks also have a broad scatter of grains between 350 and $600 \mathrm{Ma}$ with significant concentrations of zircons at 480,530 and $560 \mathrm{Ma}$ and lesser concentrations of 350-400 Ma and 1000-1100 Ma. Barbeau et al. (2010) suggested that the Trinity Peninsula Group has restricted access to sources in the Gondwana continent 
based on the subdued peaks of older Palaeozoic zircons in their samples. This could, however, be interpreted as the result of swamping of the older signal by a flood of Permian material rather that a physical barrier. The new data and the compilation of available ages from the southern rim of the Pacific by Barbeau et al. (2010) show a 'flare-up' of volcanic and plutonic magmatism in Permian times and point to a significant change in the plate tectonic regime at this time. Differing detrital zircon distributions and sandstone modes from the same region, however, show marked differences in provenance, pointing to a number of sources and discrete fluvial systems. Further, their ages are spread across the whole of the Permian period (approximate 50 million years), sufficient for a number of distinct tectonomagmatic events.

\section{Discussion}

There is no compelling evidence to suggest an accretionary complex origin for the Trinity Peninsula Group in the sense of being rocks deposited on the down-going plate and accreted to an over-riding plate, and the suggestion of deposition on or close to a preexisting continental basement is consistent with an upper plate origin. Intercalations of red chert up to several metres thick in Trinity Peninsula Group rocks of the South Orkney Islands indicate the presence of a deep-water starved basin and possibly an entrapped piece of older oceanic crust. The outliers of the Botany Bay Group suggest that both the View Point and Hope Bay areas were deformed by Early Jurassic times but evidence that the very similar Trinity Peninsula type rocks of the Miers Bluff Formation of the South Shetland Islands are of Jurassic age (Hervé et al. 2006) suggest a second younger belt of sedimentation and deformation that post-dates Late Triassic deformation (Vaughan \& Livermore, 2005) in the Antarctic Peninsula. The Trinity Peninsula Group may thus comprise two or more discrete sedimentary-tectonic tracts that amalgamated during the Mesozoic and collectively accreted to the magmatic Central Domain of Vaughan $\&$ Storey (2000) in Cretaceous times. Amalgamation of two or more lithologically similar but chronologically distinct sedimentary tracts is known also from the Torlesse rocks of New Zealand (Wandres \& Bradshaw, 2005). Their location on the Gondwana margin before Cretaceous times is uncertain, but the evidence from the View Point conglomerates clearly suggests an origin on the Gondwana margin with close links to Patagonia but also with links to the region that was either the source of the Ellsworth Mountain-type succession or was Ellsworth-like itself. The allochthonous nature of several blocks in this part of the Gondwana margin makes identifying the site of the latter source difficult, but the size of the material in the View Point conglomerates suggests the source was close and located in the future 'Weddell Sea' area. If it were the Ellsworth block, it would require intra-continental displacement to achieve the Jurassic position indicated by König \& Jokat (2006). The convergent, multi-source provenance pattern broadly resembles that proposed for Patagonia by Hervé et al. (2003; Fig. 9), but we would suggest closer proximity of the northern Antarctic Peninsula to the Ellsworth-Whitmore mountain block and possibly East Antarctica and Africa north of the Cape Fold Belt.

Contemporaneous sediments of the Duque de York Complex of the Chilean Pacific margin (Hervé, Fanning \& Pankhurst, 2003) resemble much of the Trinity Peninsula Group in having a very dominant Permian peak and a very subsidiary Devonian peak but differ in having weak and variable early Palaeozoic-Late Neoproterozoic components. They also differ from other southern Chilean metasediments in having very few older Palaeozoic zircons and lack the strong Carboniferous, Devonian and Cambrian peaks seen in the Eastern Andes Metamorphic Complex at similar latitude (Hervé, Fanning \& Pankhurst, 2003). On the whole, the age spectra in the Trinity Peninsula Group do not resemble those of the contemporaneous accretionary complex of Patagonia but seem closer to the portions of the Eastern Andes Metamorphic Complex (Augustsson et al. 2006; Hervé, Calderon \& Faundez, 2008). Some parts of this complex may be as old as Devonian (Faundez, Herve \& Lacassie, 2002) but other parts have detrital zircon peaks of Carboniferous and Permian ages (Hervé, Fanning \& Pankhurst, 2003) and probably overlap with Trinity Peninsula Group and Duque de York Complex deposition. Interestingly, both the Trinity Peninsula Group and the Eastern Andes Metamorphic Complex lack the accreted Carboniferous-Permian limestone and Permian red chert that is common in the Duque de York (subduction) Complex (Rapalini et al. 2001) and it is possible that the Eastern Andes Metamorphic Complex and the Trinity Peninsula Group share a common supra-subduction tectonic setting in Permian and Triassic times. There is little evidence of an active volcanic arc in the provenance of either unit other than the Permian zircons that due to their small size, typically less than 200 microns, could be far travelled. The origin of Permian zircons and the site of deposition of the Duque de York Complex is discussed in detail by Sepúlveda et al. (2010).

The absence of Permian zircons from the matrix of the View Point conglomerates is very surprising. It suggests that the View Point rocks are an older part of the Trinity Peninsula Group and pre-date the advent of Permian igneous activity evidenced in other sections. A Late Carboniferous or Early Permian age of deposition, contemporaneous with, or slightly younger than Gondwana glaciation is indicated. This age is consistent with the more quartzose continentderived character of the sediments and suggests an early onset of basin subsidence, possibly a far-field response to Gondwanian deformation. A possible sequence of sedimentary-tectonic events is: 
(1) Initiation of sedimentation on the subsiding trailing edge of the Deseado continental ribbon, and deposition of continental-sourced View Point conglomerate around the time of the CarboniferousPermian boundary (TPG View Pt, Fig. 10).

(2) Final continental collision of the Deseado and North Patagonia blocks (Gondwana) as proposed by Pankhurst et al. (2006), with the elimination of a subduction zone. Erosion releases abundant Permian zircons into Triassic sediments deposited along the outer edge of the continent (TPG 1, Fig. 10).

(3) Stronger convergence from the end of Triassic times and through the Early Jurassic epoch deforms the Trinity Peninsula Group of the northern Antarctic Peninsula and the Scotia Complex of the South Orkney Islands (Trouw et al. 1997; Vaughan \& Livermore, 2005). A similar or slightly younger age of deformation is reported from the Duque de York accretionary complex and for the uplift of the Diego de Almagro Schists (Thomson \& Hervé, 2002).

(4) Relaxation (roll-back) in Jurassic times (Fig. 10) with sedimentation of the Middle Jurassic Botany Bay Group (Hunter et al. 2005), Powell Island Conglomerate (Cantrill, 2000) and Miers Bluff Formation (Hervé et al. 2006). Jurassic relaxation may also be the key to the intrusion of the subcordillaran granites in Early Jurassic times (Rapela et al. 2005). The formation of the Rocas Verdes Basin and Sarmiento Ophiolite in Late Jurassic times (Stern \& de Wit, 2003) may be a further effect of this episode. A northward opening or 'unzipping' of a wedge-shaped basin is recognized by both Stern \& de Wit (2003) and Hunter et al. (2005).

(5) Cretaceous convergence, metamorphism and the formation of a foreland thrust and fold belt in Patagonia is followed by major granitic batholith intrusion. The proximity of the batholiths to the present subduction zone points to tectonic erosion of the margin at some time after the Cretaceous period.

Episodic convergence and compression on the Pacific margin has been identified by Vaughan \& Livermore (2005). A pattern of alternating extension and convergence along an active margin resembles that seen in the Palaeozoic rocks of eastern Australia (e.g. Foster, Gray \& Spaggiari, 2005; Gray \& Foster, 2004). The extension and break-up of Gondwana in Jurassic and Cretaceous times must have been accompanied by a substantial reduction in size of the Pacific basin as a whole and consequently by ocean-ward migration of subduction zones. These episodes of subduction zone retreat, possibly stimulated by mantle plumes (Storey, 1995), may well have alternated with periods of compression driven by the arrival at the subduction zone of younger buoyant crust, spreading ridges and oceanic plateaux. It is evident that from Early Permian to Cretaceous times, the sector of the Gondwana margin between Patagonia and New Zealand was extremely active and driven in part by oblique convergence, with sinistral displacement reported from the SE Pacific sector and dextral displacement in the SW Pacific. In this tectonic environment, the relative positions and relationship of events, variously dated by fossils in sediments, detrital minerals, crystallization ages in magmatic rocks and isotopic closure during post-metamorphic cooling, are difficult to integrate (Fig. 10), but because of physical limits to possible transport distances, studies of coarse and very coarsegrained sediments can provide important constraints on reconstructions.

\section{Conclusions}

The Trinity Peninsula Group of the northern Antarctic Peninsula and the South Shetland Islands has been interpreted as relatively uniform in sedimentary character and composition and has been interpreted as turbidites deposited in a submarine fan setting. This conclusion needs to be reconsidered because parts of the group might be better interpreted as the results of debris flows, slumps and slides on, or at the foot of a submarine slope near the continental edge. The Gandara olistolith probably represents a detached portion of a Triassic shelf succession that had prograded across older synglacial deposits and was subsequently involved in shelf edge collapse.

The View Point succession lacks the abundant Permian zircons typical of the Trinity Peninsula Group. Three detrital zircons from the intra-conglomerate sandstone-mudstone couplets date deposition at 302 $\pm 3 \mathrm{Ma}$, at or shortly after the Carboniferous-Permian boundary, indicating that the succession probably represents an older part of the Trinity Peninsula Group of Late Carboniferous to Early Permian age. The conglomerates are dominated by quartzite and granitoid clasts of early Palaeozoic age. Zircons from granitoid clasts and a silicic volcanic clast yield U$\mathrm{Pb}$ ages of $466 \pm 3 \mathrm{Ma}, 373 \pm 5 \mathrm{Ma}$ and $487 \pm$ $4 \mathrm{Ma}$, respectively and have corresponding average $\varepsilon \mathrm{Hf}_{\mathrm{t}}$ values between +0.3 and +7.6. A quartzite clast, conglomerate matrix and sandstone interbedded with the conglomerate units have broadly similar detrital zircon age distributions and $\mathrm{Hf}$ isotope compositions. $\mathrm{U}-\mathrm{Pb}$ zircon ages of clasts and detrital zircon ages from the sandstone matrix show good correlations with Patagonia. The clast and detrital zircon ages match well with sources within Patagonia; however, the age of one granite clast and the $\varepsilon \mathrm{Hf}$ characteristics of some detrital zircons point to a lesser South Africa or Ellsworth Mountains-like contribution, and the quartzite and granite-dominated composition of the conglomerates is similar to upper Palaeozoic diamictites in the Ellsworth Mountains. The conglomerates at View Point are not diamictites but could be either contemporaneous with Carboniferous diamictites and glacial outwash, or derived by subsequent erosion of glacial deposits. The coarseness of the deposits suggests that in Carboniferous-Permian times, before the opening of the Weddell Sea, this crustal block and the eastern side of the present Antarctic Peninsula were in close proximity. 


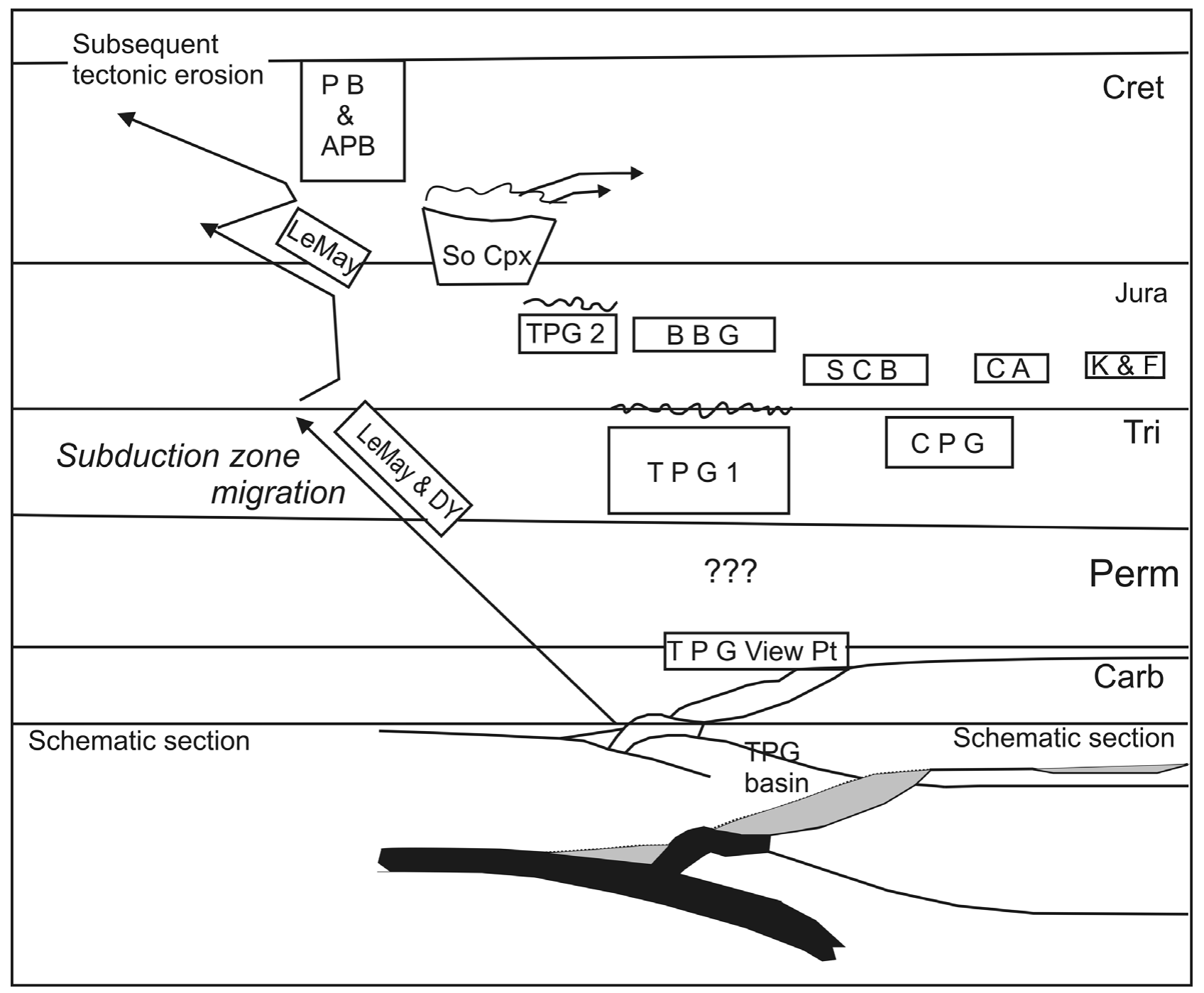

Figure 10. Schematic section and time/rock mass diagram for the Trinity Peninsula Group and other continental margin and subductionrelated units in the Antarctic Peninsula and Patagonia. Arrows on the left suggest the pattern of westward subduction zone retreat in the Permian and Mesozoic. BBG - Botany Bay Group; CA - Chon Aike suite; CPG - Central Patagonia Granites; K \& F - Karroo and Ferrar mafic suites; LeMay \& DY - older LeMay and Duque de York accretionary complexes; PB \& APB - Patagonia and Antarctic Peninsula batholiths; SCB - Subcordilleran Batholith; So Cpx - Sarmiento Complex; TPG - parcels of Trinity Peninsula Group with $\mathrm{U}-\mathrm{Pb}$ zircon age control.

The most likely sources for the abundant Permian zircons in the typical Trinity Peninsula rocks (TPG 1, Fig. 10) are magmatic rocks of northern Patagonia that were intruded following the collision and amalgamation of the Deseado terrane and the North Patagonian Massif (Pankhurst et al. 2006). The source of the bulk of the succession is most likely to be Patagonia. The Trinity Peninsula Group was probably deposited in a suprasubduction setting at an early stage of the development of a subduction zone. The Trinity Peninsula Group and the Eastern Andes Metamorphic Complex may represent parts of a related series of upper plate basins inboard of the Duque de York and LeMay accretionary complexes. The LeMay accretionary complex (Willan, 2003) appears to overlap with both the older Triassic and younger Jurassic portions of the Trinity Peninsula Group. The Gondwana margin was probably subject to alternating episodes of compression induced by the arrival of more buoyant oceanic crustal elements and extension related to roll-back of the subduction zone. Crustal extension within the Gondwana continent is documented by Dalziel \& Lawver (2001), Rapela et al. (2005) and Eagles \& Vaughan (2009).

Acknowledgements. Two of the authors (J. D. B \& R. A. J. T) thank the British Antarctic Survey for the invitation to join the expedition to View Point. We thank the captain, crew and helicopter pilots of HMS Endurance and BAS staff for their cooperation and assistance with logistics. The authors would like to thank Jon Ineson and Dave Barbeau for constructive and helpful reviews. We also thank Lev Ilyinsky and Kerstin Lindén at the NordSIMS facility, Stockholm. The facility is operated under an agreement between the research councils of Denmark, Norway and Sweden, the Geological Survey of Finland and the Swedish Museum of Natural History. This is NordSIMS contribution 274. 


\section{References}

AITKENHEAD, N. 1965. The geology of the Duse Bay-Larsen Inlet area, north-east Graham Land (with particular reference to the Trinity Peninsula Series). British Antarctic Survey Scientific Reports 51, 1-62.

AlDiss, D. T. \& EDWARDS, E. J. 1999. The geology of the Falkland Islands. In British Geological Survey Technical Report, pp. i-x, 136. Keyworth, Nottingham: British Geological Survey.

Andreis, R. R., Ribeiro, A. \& Trouw, R. A. J. 1997. Remarks on the petrofacies of Permo-Triassic turbidites from the Antarctic Peninsula, South Shetland and South Orkney Islands. In The Antarctic Region: Geological Evolution and Processes (ed. C. A. Ricci), pp. 401-7. Siena: Tipografia Senese.

Augustsson, C., Münker, C., BAhlburg, H. \& FAnNing, C. M. 2006. Provenance of late Palaeozoic metasediments of the SW South American Gondwana margin: a combined U-Pb and Hf-isotope study of single detrital zircons. Journal of the Geological Society, London 163, 983-95.

Bahlburg, H., Vervoort, J. D., Du Frane, S. A., Bock, B., Augustsson, C. \& Reimann, C. 2009. Timing of crust formation and recycling in accretionary orogens: insights learned from the western margin of South America. Earth-Science Reviews 97, 215-41.

Barbeau, D. L., Davis, J. T., Murray, K. E., Valencia, V., GeHrels, G. E., ZAHID, K. M. \& GoMBOSI, D. J. 2010. Detrital-zircon geochronology of the metasedimentary rocks of north-western Graham Land. Antarctic Science 22, 65-78.

BIRCH W. D. (ed.) 2003. Geology of Victoria. Melbourne: Geological Society of Australia.

Black, L. P., McClenaghan, M. P., Korsch, R. J., EVERARD, J. L. \& FOUdOULIS, C. 2005. Significance of Devonian-Carboniferous igneous activity in Tasmania as derived from U-Pb SHRIMP dating of zircon. Australian Journal of Earth Sciences 52, 807-29.

BRADSHAW, J. D. 2007. The Ross Orogen and Lachlan Fold Belt in Marie Byrd Land, Northern Victoria Land and New Zealand: implication for the tectonic setting of the Lachlan Fold Belt in Antarctica. In Antarctica: $A$ Keystone in a Changing World - Online Proceedings of the 10th ISAES (eds A. K. Cooper \& C. R. Raymond). USGS Open-File Report 2007-1047, Short Research Paper 059, doi:10.3133/of2007-1047.srp059, 4 pp.

CANTRILL, D. J. 2000. A new macroflora from the South Orkney Islands, Antarctica: evidence of an Early to Middle Jurassic age for the Powell Island Conglomerate. Antarctic Science 12, 185-95.

Chernicoff, C. J. \& Zappettini, E. O. 2003. Delimitation of tectonostratigraphic terranes of the southern-central region of Argentina: aeromagnetic evidences. Revista Geologica De Chile 30, 299-316.

Chernicoff, C. J., Zappettini, E. O., SAntos, J. O. S., Allchurch, S. \& MCNaughton, N. J. 2010. The southern segment of the Famatinian magmatic arc, La Pampa Province, Argentina. Gondwana Research 17, 662-75.

Corfu, F., Hanchar, J. M., Hoskin, P. W. O. \& KinnY, P. D. 2003. Atlas of zircon textures. In Zircon (eds J. M. Hanchar \& P. W. O. Hoskin), pp. 468-500. Reviews in Mineralogy and Geochemistry no. 53.

CURTIS, M. L. 2001. Tectonic history of the Ellsworth Mountains, West Antarctica: reconciling a Gondwana enigma. Geological Society of America Bulletin 113, 939-58.
Dahlquist, J. A., Pankhurst, R. J., Rapela, C. W., GAlindo, C., Alasino, P., FANNING, C. M., SAAVEDRA, J. \& BALDO, E. 2008. New SHRIMP U-Pb data from the Famatina Complex: constraining Early-Mid Ordovician Famatinian magmatism in the Sierras Pampeanas, Argentina. Geologica Acta 6, 319-33.

DALZIEL, I. W. D. 1984. Tectonic evolution of a forearc terrane, Southern Scotia Ridge, Antarctica. Geological Society of America Special Paper 200, 1-32.

DAlziel, I. W. D., Elliot, D. H., JONES, D. L., Thomson, J. W., ThOMSON, M. R. A., WeLls, N. A. \& ZinsmeIsTER, W. J. 1981. The geological significance of some Triassic microfossils from the South Orkney Islands. Geological Magazine 118, 15-25.

DALZIEL, I. W. D. \& LAWVER, L. A. 2001. The lithospheric setting of the West Antarctic Ice Sheet. In The West Antarctic Ice Sheet: Behavior and environment (eds R. B. Alley \& R. A. Bindschadler), pp. 29-44. Antarctic Research Series no. 77.

DokTOR, M., Swierczewsku, A. \& TOKARski, A. K. 1994. Lithostratigraphy and tectonics of the Miers Bluff Formation at Hurd Peninsula, Livingstone Island (West Antarctica). Studia Geologica Polonica 104, 41-104.

EAGLES, G. \& VAUGHAN, A. P. M. 2009. Gondwana breakup and plate kinematics: business as usual. Geophysical Research Letters 36, L10302, doi: 10.1029/2009g1037552, 4 pp.

Eyles, C. H. \& Lagoe, M. B. 1998. Slump-generated megachannels in the Pliocene-Pleistocene glaciomarine Yakataga Formation, Gulf of Alaska. Geological Society of America Bulletin 110, 395-408.

Faundez, V., Herve, F. \& LaCASSie, J. P. 2002. Provenance and depositional setting of pre-late Jurassic turbidite complexes in Patagonia, Chile. New Zealand Journal of Geology and Geophysics 45, 411-25.

FLOWERDEW, M. J., DALY, J. S. \& RILEY, T. R. 2007. New $\mathrm{Rb}$-Sr mineral ages temporally link plume events with accretion at the margin of Gondwana. In Antarctica: $A$ Keystone in a Changing World-Online Proceedings of the 10th ISAES (eds A. K. Cooper \& C. R. Raymond). USGS Open-File Report 2007-1047, Short Research Paper 012, doi:10.3133/of2007-1047.srp012, 4 pp.

Flowerdew, M. J., Millar, I. L., CURTIS, M. L., VAUGHAN, A. P. M., Horstwood, M. S. A., Whitehouse, M. J. \& FANNING, C. M. 2007. Combined U-Pb geochronology and $\mathrm{Hf}$ isotope geochemistry of detrital zircons from early Paleozoic sedimentary rocks, Ellsworth-Whitmore Mountains block, Antarctica. Geological Society of America Bulletin 119, 275-88.

Flowerdew, M. J., Millar, I. L. \& Vaughan, A. P. M. 2006. A combined U-Pb zircon geochronology and Hf isotope geochemistry study of detrital zircons: sedimentary provenance from West Antarctica. Terra Antarctica Reports 12, 57-64.

Flowerdew, M. J., Millar, I. L., Vaughan, A. P. M., Horstwood, M. S. A. \& FANNING, C. M. 2006. The source of granitic gneisses and migmatites in the Antarctic Peninsula: a combined U-Pb SHRIMP and laser ablation $\mathrm{Hf}$ isotope study of complex zircons. Contributions to Mineralogy and Petrology 151, 75168.

Foden, J., Elburg, M. A., Dougherty-Page, J. \& Burtt, A. 2006. The timing and duration of the Delamerian orogeny: correlation with the Ross Orogen and implications for Gondwana assembly. Journal of Geology 114, 189-210.

Foster, D. A., Gray, D. R. \& Spaggiari, C. 2005. Timing of subduction and exhumation along the Cambrian 
East Gondwana margin, and the formation of Paleozoic backarc basins. Geological Society of America Bulletin 117, 105-16.

GRAY, D. R. \& Foster, D. A. 2004. Tectonic evolution of the Lachlan Orogen, southeast Australia: historical review, data synthesis and modern perspectives. Australian Journal of Earth Sciences 51, 773-817.

Halpin, J. A., Gerakiteys, C. L., Clarke, G. L., Belousova, E. A. \& GRIFFIN, W. L. 2005. In-situ U-Pb geochronology and Hf isotope analyses of the Rayner Complex, East Antarctica. Contributions to Mineralogy and Petrology 148, 689-706.

HARRISON, S. M. \& PIERCY, B. A. 1991. Basement gneisses in northwest Palmer Land: further evidence for preMesozoic rocks in Lesser Antarctica. In Geological Evolution of Antarctica (eds M. R. A. Thomson, J. A. Crame \& J. W. Thomson), pp. 341-44. Cambridge: Cambridge University Press.

Hervé, F., Calderon, M. \& Faundez, V. 2008. The metamorphic complexes of the Patagonian and Fuegian Andes. Geologica Acta 6, 43-53.

Hervé, F., FANNING, C. M. \& PANKHURST, R. J. 2003. Detrital zircon age patterns and provenance of the metamorphic complexes of southern Chile. Journal of South American Earth Sciences 16, 107-23.

Hervé, F., Fanning, C. M., PAnKhurst, R. J., Mpodozis, C., Klepeis, K., Calderon, M. \& Thomson, S. N. 2010. Detrital zircon SHRIMP U-Pb age study of the Cordillera Darwin Metamorphic Complex of Tierra del Fuego: sedimentary sources and implications for the evolution of the Pacific margin of Gondwana. Journal of the Geological Society, London 167, 55568.

Hervé, F., Faundez, V., Brix, M. \& FAnning, M. 2006. Jurassic sedimentation of the Miers Bluff Formation, Livingston Island, Antarctica: evidence from SHRIMP $\mathrm{U}-\mathrm{Pb}$ ages of detrital and plutonic zircons. Antarctic Science 18, 229-38.

Hervé, F., LoBAto, J., UgAlde, I. \& PANKHURST, R. J. 1996. The geology of Cape Dubouzet, northern Antarctic Peninsula: continental basement to the Trinity Peninsula Group? Antarctic Science 8, 407-14.

Hunter, M. A., Cantrill, D. J., Flowerdew, M. J. \& MillaR, I. L. 2005. Mid-Jurassic age for the Botany Bay Group: implications for Weddell Sea Basin creation and southern hemisphere biostratigraphy. Journal of the Geological Society, London 162, 745-48.

Ireland, T. R., Flottmann, T., FANNING, C. M., GiBSON, G. M. \& PREISS, W. V. 1998. Development of the early Paleozoic Pacific margin of Gondwana from detritalzircon ages across the Delamerian orogen. Geology 26, 243-46.

KÖNIG, M. \& JOKAT, W. 2006. The Mesozoic breakup of the Weddell Sea. Journal of Geophysical Research-Solid Earth 111, B12102, doi:10.1029/2005jb004035, 28 pp.

MACKINNON, T. C. 1983. Origin of the Torlesse Terrane and coeval rocks, South Island, New Zealand. Geological Society of America Bulletin 94, 967-85.

MATSCH, C. L. \& OKANGAS, R. W. 1992. Stratigraphy and sedimentology of the Whiteout Conglomerate: an upper Paleozoic glaciogenic unit, Ellsworth Mountains, West Antarctica. In Geology of the Ellsworth Mountains, Antarctica (eds G. F. Webers, C. Craddock \& J. F. Splettstoesser), pp. 37-62. Geological Society of America Memoirs no. 170.

Millar, I. L., Pankhurst, R. J. \& Fanning, C. M. 2002. Basement chronology of the Antarctic Peninsula: recurrent magmatism and anatexis in the Palaeozoic
Gondwana margin. Journal of the Geological Society, London 159, 145-57.

Millar, I. L., Vaughan, A. P. M., Flowerdew, M. J., Fanning, C. M., Trouw, R. A. J. \& Bradshaw, J. D. 2003. Provenance of the Trinity Peninsula Group, northern Antarctic Peninsula. In 9th International symposium on Antarctic Earth Sciences (ed. D. K. Futterer), p. 232. Potsdam: Alfred Wegener Institute.

Milne, A. J. \& MillaR, I. L. 1991. Mid Palaeozoic basement in eastern Graham Land and its relation to the Pacific margin of Gondwana. In Geological Evolution of Antarctica (eds M. R. A. Thomson, J. A. Crame \& J. A. Thomson), pp. 335-39. Cambridge: Cambridge University Press.

OGG, J. G., OGG, G. \& Gradstein, J. M. 2008. The Concise Geological Timescale. Cambridge: Cambridge University Press.

Paciullo, F. V. P., Ribeiro, A., Andreis, R. R. \& Trouw, R. A. J. 2002. Facies associations in the ?Permian-Triassic Hope Bay Formation, Antarctic Peninsula. In Antarctica at the Close of a Millennium: Proceedings of the 8th International Symposium on Antarctic Earth Sciences (eds S. J. A. Gamble, D. N. B. Skinner \& S. Henrys), pp. 175-83. The Royal Society of New Zealand Bulletin no. 35.

Pankhurst, R. J., Rapela, C. W., Fanning, C. M. \& MARQUEZ, M. 2006. Gondwanide continental collision and the origin of Patagonia. Earth-Science Reviews 76, 235-57.

PANKhURSt, R. J., RAPEla, C. W., Loske, W. P., MARQUEZ, M. \& FAnNing, C. M. 2003. Chronological study of the pre-Permian basement rocks of southern Patagonia. Journal of South American Earth Sciences 16, 27-44.

Pickering, K. T., Stow, D. A. V., Watson, M. \& HiscotT, R. N. 1986. Deep-water facies, processes and models: a review and classification scheme for modern and ancient sediments. Earth-Science Reviews 23, 75-174.

Rapalini, A. E., Herve, F., Ramos, V. A. \& Singer, S. E. 2001. Paleomagnetic evidence for a very large counterclockwise rotation of the Madre de Dios Archipelago, southern Chile. Earth and Planetary Science Letters 184, 471-87.

Rapela, C. W., Pankhurst, R. J., Fanning, C. M. \& HERVÉ, F. 2005. Pacific subduction coeval with the Karoo mantle plume: the Early Jurassic subcordilleran belt of northwestern Patagonia. In Terrane Processes at the Margins of Gondwana (eds A. P. M. Vaughan, P. T. Leat \& R. J. Pankhurst), pp. 217-40. Geological Society of London, Special Publication no. 246.

Ribeiro, A., Andreis, R. R., Paciullo, F. V. P. \& Trouw, R. A. J. 2002. Triassic submarine fan facies association at Cape Legoupil, Antarctic Peninsula. In Antarctica at the Close of a Millennium: Proceedings of the 8th International Symposium on Antarctic Earth Sciences (eds S. J. A. Gamble, D. N. B. Skinner \& S. Henrys), pp. 169-74. The Royal Society of New Zealand Bulletin no. 35.

SCHEEPERS, R. \& ARMSTRONG, R. 2002. New U-Pb SHRIMP zircon ages of the Cape Granite Suite: implications for the magmatic evolution of the Saldania Belt. South African Journal of Geology 105, 241-56.

Sepúlveda, F. A., Palma-Heldt, S., Herve, F. \& FAnNing, C. M. 2010. Permian depositional age of metaturbidites of the Duque de York Complex, southern Chile: U$\mathrm{Pb}$ SHRIMP data and palynology. Andean Geology 37, 375-97.

Shanmugam, G. 2006. Deep-Water Processes and Facies Models: Implications for sandstone petroleum 
reservoirs. Handbook of petroleum exploration and production, 5. Amsterdam: Elsevier.

SMELliE, J. L. 1991. Stratigraphy, provenance and tectonic setting of (?) Late Palaeozoic-Triassic sedimentary sequences in northern Graham Land and South Scotia Ridge. In Geological Evolution of Antarctica (eds M. R. A. Thomson, J. A. Crame \& J. W. Thomson), pp. 411-17. Cambridge: Cambridge University Press.

SMELliE, J. L. \& MillaR, I. L. 1995. New K-Ar isotopic ages of schists from Nordenskold Coast, Antarctic Peninsula: oldest part of the Trinity Peninsula Group. Antarctic Science 7, 191-96.

SMellie, J. L., RoberTs, B. \& HiRONS, S. R. 1996. Very lowand low-grade metamorphism in the Trinity Peninsula Group (Permo-Triassic) of northern Graham Land, Antarctic Peninsula. Geological Magazine 133, 583-94.

SÖllner, F., Miller, H. \& HeRVE, M. 2000. An Early Cambrian granodiorite age from the pre-Andean basement of Tierra del Fuego (Chile): the missing link between South America and Antarctica? Journal of South American Earth Sciences 13, 163-77.

STERN, C. R. \& DE WIT, M. J. 2003. Rocas Verdes ophiolites, southernmost South America: remnants of progressive stages of development on oceanic-type crust in a continental margin back-arc basin. In Ophiolites in Earth History (eds Y. Dilek \& P. T. Robinson), pp. 66583. Geological Society of London, Special Publication no. 218.

Stone, P. \& Thomson, M. R. A. 2005. Archaeocyathan limestone blocks of likely Antarctic origin in Gondwanan tillite from the Falkland Islands. In Terrane Processes at the Margins of Gondwana (eds A. P. M. Vaughan, P. T. Leat \& R. J. Pankhurst), pp. 347-58. Geological Society of London, Special Publication no. 246.

STOREY, B. C. 1995. The role of mantle plumes in continental breakup: case histories from Gondwanaland. Nature 377(6547), 301-08.

Storey, B. C. \& GARRETT, S. W. 1985. Crustal growth of the Antarctic Peninsula by accretion, magmatism and extension. Geological Magazine 122, 5-14.

Thomas, R. J., JacobS, J., HorStwood, M. S. A., UedA, K., Bingen, B. \& MATOLA, R. 2010. The Mecúburi and Alto Benfica Groups, NE Mozambique: aids to unravelling ca. 1 and $0.5 \mathrm{Ga}$ events in the East African Orogen. Precambrian Research 178, 72-90.

Thomson, M. R. A. 1975. New palaeontological and lithological observations on the Legoupil Formation, north-west Antarctic Peninsula. British Antarctic Survey Bulletin 41-42, 169-85.

Thomson, S. N. \& Hervé, F. 2002. New time constraints for the age of metamorphism at the ancestral Pacific Gondwana margin of southern Chile $\left(42^{\circ} \mathrm{S}-52^{\circ} \mathrm{S}\right)$. Revista Geologica De Chile 29, 255-71.

Trouw, R. A. J., Passchier, C. W., Simoes, L. S. A., ANDREIS, R. R. \& VAleriano, C. M. 1997. Mesozoic tectonic evolution of the South Orkney microcontinent, Scotia arc, Antarctica. Geological Magazine 134, 383401.

Vaughan, A. P. M. \& Livermore, R. A. 2005. Episodicity of Mesozoic terrane accretion along the Pacific margin of Gondwana: implications for superplume-plate interactions. In Terrane Processes at the Margins of Gondwana (eds A. P. M. Vaughan, P. T. Leat \& R. J. Pankhurst), pp. 143-78. Geological Society of London, Special Publication no. 246.
Vaughan, A. P. M. \& Storey, B. C. 2000. The eastern Palmer Land shear zone: a new terrane accretion model for the Mesozoic development of the Antarctic Peninsula. Journal of the Geological Society, London 157, 1243-56.

Veevers, J. J. \& SAeEd, A. 2007. Central Antarctic provenance of Permian sandstones in Dronning Maud Land and the Karoo Basin: integration of $\mathrm{U}-\mathrm{Pb}$ and TDM ages and host-rock affinity from detrital zircons. Sedimentary Geology 202, 653-76.

Visser, J. N. J., Hall, K. J. \& LoOCK, J. C. 1986. The application of stone counts in the glacigene Permo-Carboniferous Dwyka Formation, South Africa. Sedimentary Geology 46, 197-212.

WALKER, R. G. 1992. Turbidites and submarine fans. In Facies Models: Response to sea-level change, no. GT1 (eds R. G. Walker \& N. P. James), pp. 23963. St Johns, Newfoundland: Geological Association of Canada.

WANDres, A. M. \& Bradshaw, J. D. 2005. New Zealand tectonostratigraphy and implications from conglomeratic rocks for the configuration of the SW Pacific of Gondwana. In Terrane Processes at the Margins of Gondwana (eds A. P. M. Vaughan, P. T. Leat \& R. J. Pankhurst), pp. 179-216. Geological Society of London, Special Publication no. 246.

WANDRES, A. M., BradshaW, J. D., WeaVer, S., MAas, R., Ireland, T. \& EbY, N. 2004. Provenance of the sedimentary Rakaia sub-terrane, Torlesse Terrane, South Island, New Zealand: the use of igneous clast compositions to define the source. Sedimentary Geology 168, 193-226.

Whitehouse, M. J., Kamber, B. S. \& Moorbath, S. 1999. Age significance of U-Th- $\mathrm{Pb}$ zircon data from early Archaean rocks of west Greenland - a reassessment based on combined ion-microprobe and imaging studies. Chemical Geology 160, 201-24.

Will, T. M., Frimmel, H. E., ZeH, A., Le RouX, P. \& SCHMADICKE, E. 2010. Geochemical and isotopic constraints on the tectonic and crustal evolution of the Shackleton Range, East Antarctica, and correlation with other Gondwana crustal segments. Precambrian Research 180, 85-112.

Will, T. M., ZEH, A., GeRDES, A., FrimMEL, H. E., Millar, I. L. \& Schmadicke, E. 2009. Palaeoproterozoic to Palaeozoic magmatic and metamorphic events in the Shackleton Range, East Antarctica: constraints from zircon and monazite dating, and implications for the amalgamation of Gondwana. Precambrian Research 172, 25-45.

WiLlan, R. C. R. 2003. Provenance of Triassic-Cretaceous sandstones in the Antarctic Peninsula: implications for terrane models during Gondwana breakup. Journal of Sedimentary Research 73, 1062-77.

WILLIAMS, I. S. 1998. U-Th-Pb geochronology by ion microprobe. In Applications of Microanalytical Techniques to Understanding Mineralizing Processes (eds M. A. McKibben, W. C. Shanks \& W. I. Ridley), pp. 1-35. Socorro, New Mexico: Society of Economic Geologists Publishing Company.

Zeh, A., Gerdes, A. \& BARTon, J. M. 2009. Archean accretion and crustal evolution of the Kalahari Craton: the zircon age and $\mathrm{Hf}$ isotope record of granitic rocks from Barberton/Swaziland to the Francistown Arc. Journal of Petrology 50, 933-66 